\title{
Retrograde Signaling onto Ret during Motor Nerve Terminal Maturation
}

\author{
Christel Baudet, ${ }^{1 \star}$ Ester Pozas, ${ }^{1 *}$ Igor Adameyko, ${ }^{1}$ Elisabet Andersson, ${ }^{2}$ Johan Ericson, ${ }^{2}$ and Patrik Ernfors ${ }^{1}$ \\ ${ }^{1}$ Division of Molecular Neurobiology, Department of Medical Biochemistry and Biophysics, and ${ }^{2}$ Department of Cell and Molecular Biology, Karolinska \\ Institute, 17177 Stockholm, Sweden
}

\begin{abstract}
Establishment of the neuromuscular synapse requires bidirectional signaling between the nerve and muscle. Although much is known on nerve-released signals onto the muscle, less is known of signals important for presynaptic maturation of the nerve terminal. Our results suggest that the Ret tyrosine kinase receptor transmits a signal in motor neuron synapses that contribute to motor neuron survival and synapse maturation at postnatal stages. Ret is localized specifically to the presynaptic membrane with its ligands, GDNF (glial cell line-derived neurotrophic factor)/NTN (neurturin), expressed in skeletal muscle tissue. Lack of Ret conditionally in cranial motor neurons results in a developmental deficit of maturation and specialization of presynaptic neuromuscular terminals. Regeneration of Ret-deficient adult hypoglossal motor neurons is unperturbed, but despite contact with the unaffected postsynaptic specializations, presynaptic axon terminal maturation is severely compromised in the absence of Ret signaling. Thus, Ret transmits a signal in motor nerve terminals that participate in the organization and maturation of presynaptic specializations during development and during regeneration in the adult.
\end{abstract}

Key words: neuromuscular junction; neurotrophic factors; development; nerve terminal; synaptic vesicles; Ret

\section{Introduction}

Synaptogenesis requires the coordination between presynaptic and postsynaptic elements through which the structures assemble and mature. This is achieved by sets of signals passing between the cells and which initiate and maintain the synaptic apparatus leading postsynaptically to the organization of scaffolding proteins, signaling receptors, and neurotransmitter receptors. One of the best studied synapses is the vertebrate skeletal neuromuscular synapse. Assembly of the postsynaptic neuromuscular synapse depends on Agrin released from motor nerve terminals (Godfrey et al., 1984; McMahan, 1990; Sanes and Lichtman, 2001; Burden, 2002) that via interactions with its receptor the muscle-specific receptor tyrosine kinase (MuSK) (DeChiara et al., 1996) organize postsynaptic differentiation by clustering acetylcholine receptors (AChRs) and by increasing AChR expression

\footnotetext{
Received June 11, 2007; revised Nov. 23, 2007; accepted Nov. 27, 2007.

This work was supported by the Swedish Research Council (P.E., C.B.), The Swedish Cancer Society (P.E.), Karolinska Foundation (E.P.), and the Swedish Foundation for Strategic Research (Center of Excellence in Developmenta Biology Grant to P.E.). We thank the personnel at Karolinska Center for Transgene Technologies, mainly Dr. Johannes Wilbertz for giving us E14 ES cells and performing blastocysts injections of ES clones, the personnel of the Scheele Animal House (Evis A. and Veronica P.), and Claudia Tello and Johnny Soderlund for technical support. We are grateful to Sebastian Thams for instructions on nerve lesions.

${ }^{*}$ C.B. and E.P. contributed equally to this work.

Correspondence should be addressed to Dr. Patrik Ernfors, Division of Molecular Neurobiology, Department of Medical Biochemistry and Biophysics, Karolinska Institute, 17177 Stockholm, Sweden. E-mail: patrik.ernfors@ki.se. C. Baudet's present address: EA2406, Université Victor Ségalen Bordeaux 2, 33076 Bordeaux, France.

E. Pozas's present address: Department of Brain Ischemia and Neurodegeneration, Institut d'Investigacions Biomèdiques de Barcelona-Consejo Superior de Investigaciones Científicas, Institut d'Investigacions Biomèdiques August Pi i Sunyer, 08036 Barcelona, Spain.

DOI:10.1523/JNEUROSCI.4489-07.2008

Copyright $\odot 2008$ Society for Neuroscience $\quad$ 0270-6474/08/280963-13\$15.00/0
}

only in the myonuclei closely aligned to the nerve-muscle contact (Sanes and Lichtman, 2001; Burden, 2002).

Mice lacking Agrin, MuSK, and Rapsyn, which couples MuSK activation to AChR clustering, have deficits also in presynaptic specialization (Gautam et al., 1995), suggesting a signal also onto axon terminals that is necessary for presynaptic maturation. In agreement with this, recent in vivo data show that fibroblast growth factors (FGFs) participate in the concentration of synaptic vesicles transiently during embryonic stages, and together with a postnatal requirement of extracellular matrix (ECM) proteins participate in presynaptic motor nerve terminal maturation (Fox et al., 2007). However, the considerable differentiation even in the absence of both FGF signaling and ECM components predict the existence of other presynaptic organizers (Fox et al., 2007). Such candidate target-derived molecules could be neurotrophic factors that not only provide necessary trophic signals for neuronal survival during development but also promote cell differentiation, axonal growth, and maturation of many central and peripheral neuronal cell types (Bibel and Barde, 2000; Ernfors, 2001). Glial cell line-derived neurotrophic factor (GDNF) is one of the most potent survival factors for motor neurons in culture (Henderson et al., 1994; Oppenheim et al., 1995) and regulates motor neuron survival also in vivo during embryogenesis (Moore et al., 1996; Sanchez et al., 1996; Garces et al., 2000; Mikaels et al., 2000; Oppenheim et al., 2000). In transgenic mouse overexpression experiments, GDNF affects axonal branching of motor neurons (Nguyen et al., 1998; Keller-Peck et al., 2001) and increases the size or amplitude and the frequency of spontaneous synaptic currents (Wang et al., 2002; Lu and Je, 2003). These results place GDNF as a candidate signaling molecule at the neuromuscular synapse. 
Because mouse mutants lacking Ret signaling die at birth as a result of the failure of kidney development, little is known of the physiological role of GDNF and Ret activation for motor neuron survival and for development of the neuromuscular synapse. Our finding that Ret is concentrated at the presynaptic nerve terminal opened for its direct participation in shaping the neuromuscular synapse. We report that Ret signaling promotes motor neuron survival and maturation of neuromuscular synapses throughout postnatal and adult life.

\section{Materials and Methods}

Animals. Generation of the ret conditional knock-out mice (Ret ${ }^{\text {flox }}$ ) was as follows: A 129/Sv mouse genomic BAC clone containing the ret gene was obtained from Research Genetics (Huntsville, AL). Two overlapping fragments covering a $12 \mathrm{~kb}$ portion of the ret gene (protein coding exons 7-17) have been identified by enzymatic restriction and Southern analysis. To target the ret locus, we used the pFlrtl vector, generated by Orban PC (University of British Columbia, Vancouver, British Columbia, Canada) in which we have inserted a $1.2 \mathrm{~kb}$ fragment containing exons 12 and 13 between the two lox-P sites, upstream of the frt-flanked neomycin resistance cassette (neo). 129/Ola-derived E14 embryonic stem (ES) cells were then screened by Southern blotting for homologous recombination of the targeting construct after electroporation, using a $1.6 \mathrm{~kb}$ external probe and a $1.3 \mathrm{~kb}$ internal probe. Two independent ES cell clones were used to generate the Ret ${ }^{\text {flox-neo/+ }}$ mice. Germline transmission of the floxed ret allele was verified by PCR analysis. Crossing Ret ${ }^{\text {flox-neo/+ }}$ mice with ACTB:Flpe transgenic mice (Rodriguez et al., 2000) allowed us to remove the neo-cassette and generate the Ret ${ }^{\text {flox/+ }}$ animals. Mice homozygous for the modified allele were born at Mendelian frequency and survived through adulthood. Ret kinase dead mutants $\left(\operatorname{Ret}^{\Delta / \Delta}\right)$ were then obtained by breeding the offspring born from the crossing of $\mathrm{Ret}^{\text {flox/+ }}$ animals with PGK:Cre mice (Lallemand et al., 1998). Mice homozygous for the mutant allele were born at Mendelian frequency and die at birth. Nkx6.2+/lz mice have been described previously (Vallstedt et al., 2001). Nkx6.2+/cre mice were generated following the same strategy inserting a Cre/PGKneo cassette in place of the lacZ/PGKneo cassette. Genotyping was performed by PCR; primers and protocols are available on request. The mice used in this study were kept on a C57BL/6 genetic background. Ret ${ }^{\text {flox/flox }}$ and $\operatorname{Ret}^{\Delta / \Delta}$ mice are available through the European Mouse Mutant Archive (www.emmanet.org) as Retflox EM:02080 and RetKO EM:02081.

Tissue preparation. Embryos were collected at different stages [from embryonic day 10 (E10) to E18], directly fixed in 4\% paraformaldehyde (PFA) at $4^{\circ} \mathrm{C}$ (from 2 to $18 \mathrm{~h}$ depending on their age), rinsed with PBS, and preserved at $4^{\circ} \mathrm{C}$ in $30 \%$ sucrose-PBS until further use. Also, after overnight fixation of E18 embryos, kidneys and urogenital system were dissected out to be photographed; tongues were dissected out and maintained in 30\% sucrose-PBS for additional analysis. Brainstems, spinal cords, and tongues were dissected out from adult (3-4 months of age) or aged ( $>12$ months of age) female mice after perfusion with $4 \%$ PFA, postfixed overnight in $4 \%$ PFA at $4^{\circ} \mathrm{C}$, rinsed with PBS, and stored at $4^{\circ} \mathrm{C}$ in $30 \%$ sucrose-PBS before cryosectioning. Brainstems were also dissected out from E11.5, E13.5, and E15.5 embryos, and they were fixed overnight in $4 \% \mathrm{PFA}$ at $4^{\circ} \mathrm{C}$ in an "open-book" configuration, rinsed with PBS, and stored at $4^{\circ} \mathrm{C}$ in $30 \%$ sucrose-PBS until additional use. For whole-mount in situ hybridization, the embryos were dehydrated in methanol, rehydrated, treated with proteinase K, and refixed. For in situ hybridization and immunohistochemistry on cryosections, the embryos (up to E18) and adult tissues were mounted onto a mold with OCT, snap-frozen on dry ice, coronally (CNS tissue) or transversally (muscle) sectioned $(16 \mu \mathrm{m})$, and collected on alternating slides in four or six series, respectively. Before use, the sections were air-dried $1-2 \mathrm{~h}$ at room temperature. For whole-mount immunochemistry, embryos were postfixed overnight in cold Dent's fixative (one part DMSO, four parts methanol), bleached, and rehydrated. For real-time PCR, segments of the brainstem dissected out from E11.5 embryos were snap frozen on dry ice before use.

Probes. The extracellular domain (ECD) of the mouse ret, the exons 12 and 13 of the mouse ret (ex12-13), the full-length mouse GDNF, and mouse Islet 1 were amplified by reverse transcription (RT)-PCR and either subcloned using a TOPO TA cloning kit from Invitrogen (Carlsbad, CA) or ligated into the PCDNA3 vector. Specific digoxigeninlabeled antisense probes were synthesized according to supplier's instructions (Roche, Indianapolis, IN) to perform nonradioactive in situ hybridization.

Nonradioactive in situ hybridization procedures. Sections were hybridized overnight at $70^{\circ} \mathrm{C}$ with a solution containing $0.19 \mathrm{M} \mathrm{NaCl}, 10 \mathrm{mM}$ Tris, pH 7.2, 5 mм NaH${ }_{2} \mathrm{PO}_{4} 2 \mathrm{H}_{2} \mathrm{O} / \mathrm{Na}_{2} \mathrm{HPO}_{4}, \mathrm{pH}$ 6.8, 50 mм EDTA, $50 \%$ formamide, $10 \%$ dextran sulfate, $1 \mathrm{mg} / \mathrm{ml}$ yeast tRNA, $1 \times$ Denhardt solution, and $100-200 \mathrm{ng} / \mathrm{ml}$ probe. Sections were then washed four times $20 \mathrm{~min}$ at $65^{\circ} \mathrm{C}$ in $0.4 \times \mathrm{SSC}, \mathrm{pH} 7.5,50 \%$ formamide, $0.1 \%$ Tween 20, and three times $20 \mathrm{~min}$ at room temperature in MABT $(0.1 \mathrm{M}$ maleic acid, $0.15 \mathrm{M} \mathrm{NaCl}$, and $0.1 \%$ Tween $20, \mathrm{pH} 7.5)$. Sections were blocked for $1 \mathrm{~h}$ at room temperature in presence of $20 \%$ goat serum and $2 \%$ blocking agent (Roche) before an overnight incubation with alkaline phosphatase (AP)-conjugated antibody (Roche; 1:2000). After extensive washes with MABT, revelation was performed using nitroblue tetrazolium (NBT) and 5-bromo-4-chloro-3-indolyl phosphate (BCIP) (Roche) in $100 \mathrm{~mm}$ Tris-HCl, pH 9.5, $100 \mathrm{~mm} \mathrm{NaCl}, 50 \mathrm{~mm} \mathrm{MgCl}_{2}$, and $0.1 \%$ Tween 20 (NTMT). As for the whole embryos and brainstems, they were prehybridized for $1 \mathrm{~h}$ at $70^{\circ} \mathrm{C}$ in $1.3 \times$ SSC, $50 \%$ formamide, $2 \%$ Tween 20,0.5\% CHAPS (3-[(3-cholamidopropyl)dimethylammonio]1-propanesulfonate), $5 \mathrm{~mm}$ EDTA, and $50 \mu \mathrm{g} / \mathrm{ml}$ yeast tRNA. Hybridization was performed overnight with digoxigenin-labeled riboprobes in the same buffer. Washes with hybridization buffer were followed by RNase treatment and subsequent washes with hybridization buffer at $65^{\circ} \mathrm{C}$. Samples were then blocked in MABT containing 20\% goat serum and incubated overnight at $4^{\circ} \mathrm{C}$ with AP-conjugated antibody (Roche; 1:2000 in MABT with 2\% goat serum). After extensive washes with MABT, revelation was performed using NBT and BCIP (Roche; in NTMT).

Immunostaining and histology. Primary antibodies were used at the following dilutions: Ret (1:500; Santa Cruz, Santa Cruz, CA), Peripherin (1:500; Chemicon, Temecula, CA), Islet1 (1:100; Developmental Studies Hybridoma Bank, Iowa City, IA), Neurofilaments (1:500; Sigma, St. Louis, MO), Synapsin I (1:1000; Biogenesis, Bournemouth, UK), Synaptophysin (1:150; Zymed, San Francisco, CA), and Snap-25 (1:2000; Biosite, San Diego, CA). They were incubated at room temperature for $1-2 \mathrm{~h}$ or overnight at $4^{\circ} \mathrm{C}$ and detected using either species-specific fluorescent antibodies (donkey Cy2-, Cy3-, Cy5-, or Alexa-conjugated antibodies, 1:500 (Jackson ImmunoResearch, West Grove, PA; Invitrogen) or using a Vectastain $\mathrm{ABC}$ kit (Vector Labs, Burlingame, CA) with DAB for detection. $\alpha$-Bungarotoxin, Alexa Fluor 488 conjugated (1:1000; Invitrogen) was used to visualized endplates in the tongue, buccinator, and oculomotor muscles. X-Gal staining of whole embryos was performed overnight at room temperature in phosphate buffer containing $3.1 \mathrm{~mm}$ FeK3(CN)6, $3.1 \mathrm{~mm}$ FeK4(CN)6, and $0.4 \mathrm{mg} / \mathrm{ml} \mathrm{X-gal.}$

Cresyl violet staining was performed on one series of sections through the brainstem for total neuronal count. Pictures were taken through a Zeiss (Oberkochen, Germany) Axioplan2, a Zeiss Axiovert 100M, a Zeiss LSM 510 confocal, or a Stemi 2000-C microscope.

Neuron quantification on cryosections. Neuronal numbers in E18 and adult nuclei were established by counting neurons with a clear nucleus in every fourth or sixth section, respectively. The number of neurons was estimated using the following equation: $N=n T /(T+D)$, where $n$ is the number of neurons counted multiplied by section separation, $T$ is the thickness of the section, and $D$ is the average diameter of a nucleus, estimated to $\sim 10 \mu \mathrm{m}$ at E18 and $\sim 15 \mu \mathrm{m}$ in the adult (Abercrombie, 1946).

Primary cell and organotypic cultures. Neural tubes from E11.5 embryos were dissected out. For primary culture purpose, rhombomeres 4-6 (containing the migrating facial motoneurons) and rhombomere 8 (containing the condensing hypoglossal motoneurons) were separated. Cells were dissociated and cultured at a high density for $6 \mathrm{~h}$ following a previously described protocol (Baudet et al., 2000). For organotypic culture, the intact neural tube was maintained in an open-book configuration and cultured also for $6 \mathrm{~h}$ in a defined medium described previously (Pozas and Ibanez, 2005). GDNF and neurturin (NTN) (Promega, Madison, WI) were used at $50 \mathrm{ng} / \mathrm{ml}$. 
Axonal length. Primary culture were fixed with 4\% PFA after 6 h, washed three times with PBS, permeabilized in PBT [1\% bovine serum albumin (BSA), $0.3 \%$ Triton X-100 in PBS] for $20 \mathrm{~min}$, and stained to reveal Islet1 and Peripherin expression. Cells expressing both proteins are recognized as motoneurons, and their axon is measured. Fifty to 100 motoneurons were randomly photographed for each culture condition, and the measurements were made using the NeuronJ plugin of $\mathrm{NIH}$ Image/J software.

Neurofilament quantification. After neurofilament immunostaining, 20 evenly spaced images per animal through the extent of the lesioned one-half of the tongue were acquired by a LSM 5.1 scanning microscope (Zeiss). Every image consisted of the scanning of a volume of $643 \times$ $643 \times 20 \mu \mathrm{m}$ that was projected into a bidimensional image. The fraction of the area occupied by the staining was measured after threshold normalization with the NIH Image/J software. At least three animals were analyzed per genotype.

Endplate quantification and neuromuscular junction analysis. After $\alpha$-bungarotoxin, Alexa Fluor 488-conjugated staining, the total number of the endplates was counted in every fourth section at E18 and every sixth section in adult and multiply by the number of sections to get the total number in the whole tongue. Endplates were randomly photographed using a Zeiss microscope with the same image capture settings in normal and lesioned animals. The area of the endplate was delimited and the total intensity of synapsin I, synaptophysin, and bungarotoxin staining per synapse was measured using the NIH Image/J software. The data were normalized to the average background in each image by the same software. At least three different animals were analyzed per genotype and between 70 and 100 endplates per animal.

Quantitative real-time PCR. Total RNA were isolated from each sample of the organotypic culture using RNeasy (Qiagen, Hilden, Germany). Single-stranded cDNA were synthesized using SuperScript (Invitrogen) and oligo-d(T) 15 primers (Promega). A 64 bp amplicon was obtained using the following primers: for ret forward, 5'-CTTGGCAGAAATGAAGCTTGTACA-3', and reverse, 5'-GTCCCTCAGCCACCAAGATGT-3'; GDNF forward, TCC TGA CCA GTT TGA TGA CG, and reverse, AAC ATG CCT GGC CTA CTT TG; NTN forward, GCT CCC TGC TAT CTG TCT GG, and reverse, GTC TCA TCC GAC GTG TAG CC; $\operatorname{artemin}(\mathrm{ART})$ forward, ATT TGT GCA GCG AAA GAA CC, and reverse, ATG AAG GAG ACG GCC TCA TA; and persephin (PSP) forward, ATC CTG TGT CTG CTG CTC CT, and reverse, CAA GGA AGG TCA CAT CAG CA. Real-time PCR was performed on a PerkinElmer (Wellesley, MA) ABI Prism 5700 using SYBR Green Master Mix (Applied Biosystems, Foster City, CA) with the following thermal profile. HPRT (hypoxanthine phosphoribosyltransferase) was used as an external control (5'-GAATCTGCAAATACGAGGAGTCCT-3' and 5'-CTTTACTAGGCAGATGGCCACA-3').

Lesion. Surgical procedures were performed on 3- to 4-month-old female mice under anesthesia with intraperitoneal injection of ketamine ( $75 \mathrm{mg} / \mathrm{kg}$ body weight) and medetomidine ( $1 \mathrm{mg} / \mathrm{kg}$ body weight). After surgery, atipamezol ( $\sim 60 \mathrm{mg} / \mathrm{kg}$ body weight) was injected subcutaneously to reverse the effects of medetomidine. In one group of animals, the main trunk of the left facial nerve main trunk was exposed caudally to the external auditory meatus. The nerve was transected using a pair of scissors, and the wound was immediately closed. In another group of animals, the left hypoglossal nerve was carefully exposed proximal to its bifurcation at the hyoid bone and the nerve was transected. In all experiments, the unoperated contralateral side served as a control. After $21 \mathrm{~d}$, the animals were killed and perfused $(n=3$ control mice and $N=9$ $\mathrm{Ret}^{\text {Nkx6.2-cre }}$ mice for each lesion paradigm).

Ethical approval of animal studies. Animal experiments conformed to the European Communities Council Directive (86/609/EEC) and were approved by the Stockholm North Ethical Board on Laboratory Animals (N17/03, N293/05, and N385/04).

\section{Results}

Concentration of Ret receptors at the neuromuscular synapse In order for Ret to transmit a retrograde signal, the protein would be expected to be concentrated to the neuromuscular synapse. Immunostainings of the intrinsic muscles of the tongue, a target
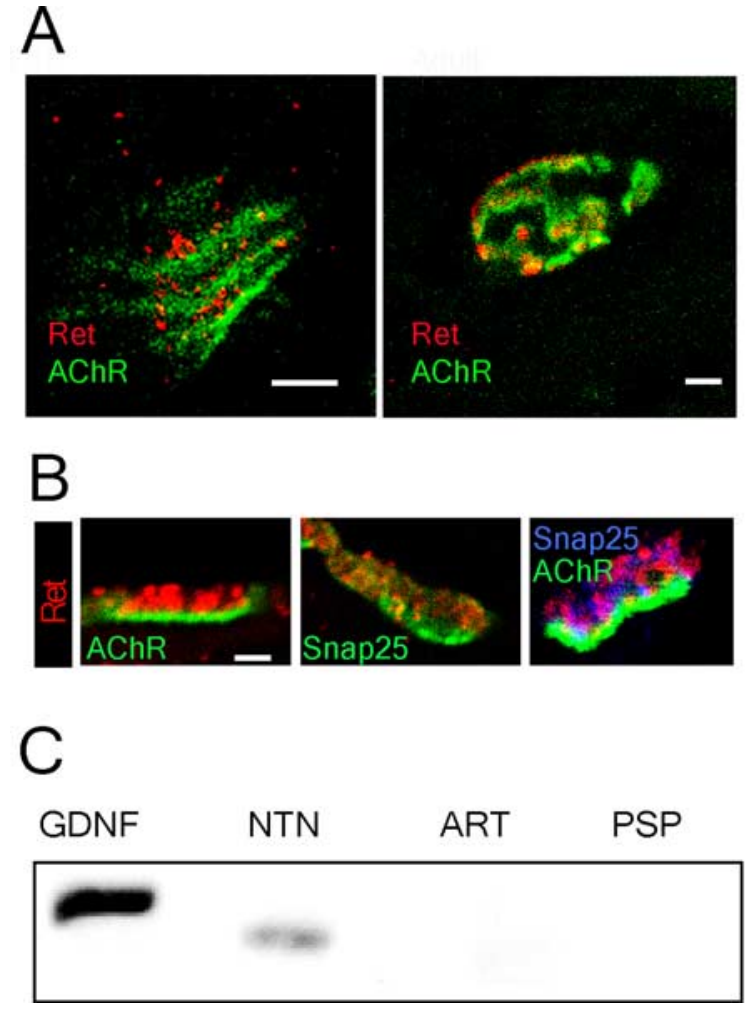

Figure 1. Concentration of Ret receptors presynaptically in the neuromuscular synapse and expression of GDNF family ligands in the target tissue. $\boldsymbol{A}$, Double labeling for Ret and AChRs (bungarotoxin binding) on the internal muscle of the tongue shows the presence of Ret in the neuromuscular synapse of $E 18$ and adult mice. $\boldsymbol{B}$, Confocal images show the specific presence of Ret receptors in the presynaptic area (labeled by Snap- 25 immunohistochemistry) but not in the postsynaptic membrane (stained by bungarotoxin binding to AChRs). C, RT-PCR for all GDNF family ligands shows the expression of GDNF and NTN in the neonatal tongue. Scale bars, $4 \mu \mathrm{m}$.

of hypoglossal motor neurons, were performed from E18 and adult mice with antibodies against Ret combined with the localization of AChRs using fluorescently conjugated $\alpha$-bungarotoxin. Ret immunoreactivity was revealed at E18 by a punctuate staining overlying forming postsynaptic AChR clusters. The staining appeared to be concentrated to the neuromuscular synapse, because only weak and occasional staining was seen in axons within the muscle. Adult neuromuscular synapses displayed a strong Ret immunoreactivity matching closely the elaborate postsynaptic specialization of the neuromuscular synapse (Fig. 1A). We next determined whether Ret is located presynaptically or postsynaptically. Thick sections were stained for Ret and AChRs, which are localized postsynaptically, or for Ret and synaptosome-associated protein of $25 \mathrm{kDa}$ (SNAP25), which is a presynaptic protein, and thin optical sections through the thickness of the sections were acquired using a confocal microscopy. The reconstructed neuromuscular synapses revealed Ret in the nerve terminals overlaying the AChR containing postsynaptic membrane. Consistently, Ret also colocalized with the presynaptic protein SNAP25 (Fig. $1 B$ ). This finding shows that Ret receptors are concentrated at the presynaptic terminal of the synapse. We examined which ligand(s) were expressed in the muscle tissue and therefore could be acting on Ret. mRNA expression of the Ret ligands GDNF, NTN, ART, and PSP was examined in the muscle by RT-PCR. Strong expression of GDNF and lower levels of NTN were detected, whereas neither ART nor PSP was found expressed in the muscle (Fig. 1C). 


\section{Conditional inactivation of Ret in cranial motor neurons}

We addressed whether the expression of Ret in motor neuron nerve terminals reflect a function for cell survival, axonal growth, and/or for differentiation and maturation of the neuromuscular synapse. Ret-null mutant mice die at birth and can therefore not be used for determining its roles at later developmental stages. Because of this, and to address whether Ret plays a cell-autonomous function for motor neurons, mice carrying inactivated Ret specifically in cranial motor neurons were established. Using the Cre-LoxP recombination system, mice carrying a conditional allele of Ret with exon 12 and 13 flanked by LoxP sites were generated (Fig. $2 A, B$ ). The PGKneo cassette was eliminated in these mice by crossing with a deleter FLP mouse strain to generate Ret ${ }^{\text {flox/flox }}$ mice. To specifically delete Ret in cranial motor neurons, mice expressing Cre under the Nkx6.2 promoter were generated. These mice were produced by inserting a Cre/ PGKneo cassette in place of the lacZ/PGKneo cassette into a previously described targeting vector (Vallstedt et al., 2001). The resulting Nkx6.2 $2^{+/ \text {cre }}$ mice were crossed to Ret ${ }^{\text {flox/flox }}$ mice to produce animals carrying the Nkx6.2 $2^{+/ \text {cre }}$ alleles and homozygous for the floxed Ret allele, producing a mouse strain with a specific deletion of Ret in cranial motor neurons (Ret ${ }^{\mathrm{Nkx6.2-cre}}$ mice). Ret $^{\mathrm{Nkx6.2-cre}}$ mice survived into adulthood with an expected frequency, were fertile, and did not show any gross phenotype. Ret-null mutant mice $\left(\operatorname{Ret}^{\Delta / \Delta}\right)$, generated by breeding the Ret $^{\text {flox/flox }}$ alleles to a deleter Cre mouse strain (PGK:cre), died at birth similar to previously described Ret-null mutant mice (Schuchardt et al., 1994). Ret ${ }^{\text {Nkx6.2-cre }}$ mice, similar to wild-type mice, developed normal kidneys, whereas kidney development failed in $\operatorname{Ret}^{\Delta / \Delta}$ mice (Fig. 2C). Ret mRNA expression was unperturbed in spinal cord motor neurons and dorsal root ganglia of Ret ${ }^{\mathrm{Nkx6} \text {.2-cre }}$ mice (Fig. 2 C), but was mostly eliminated from cranial motor neurons of the facial (VII) and hypoglossal (XII) motor nuclei in E18 embryos as seen with an in situ hybridization probe against exons 12 and 13 ("ex 12-13" probe) of the Ret gene (Fig. 2D). The successful elimination of Ret expression was confirmed in the adult with the ex $12-13$ probe (Fig. $2 E)$. However, when using a probe directed against the Ret ECD, Ret transcripts could be detected in the hypoglossal motor nucleus both at E18 and in the adult (Fig. $2 E$ ). Cell count showing expression with the ECD probe is presented in Figure $2 F$.
A

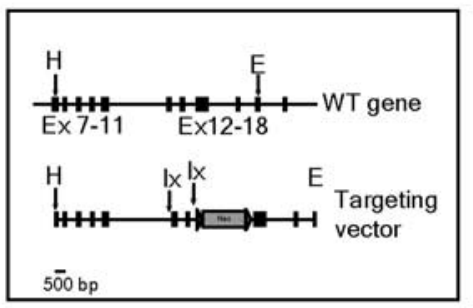

B

C WT

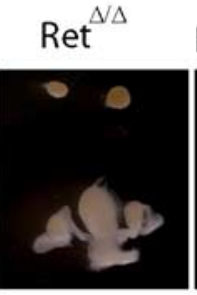

Ret $^{\mathrm{Nkx6} 6.2-\mathrm{cre}}$

D
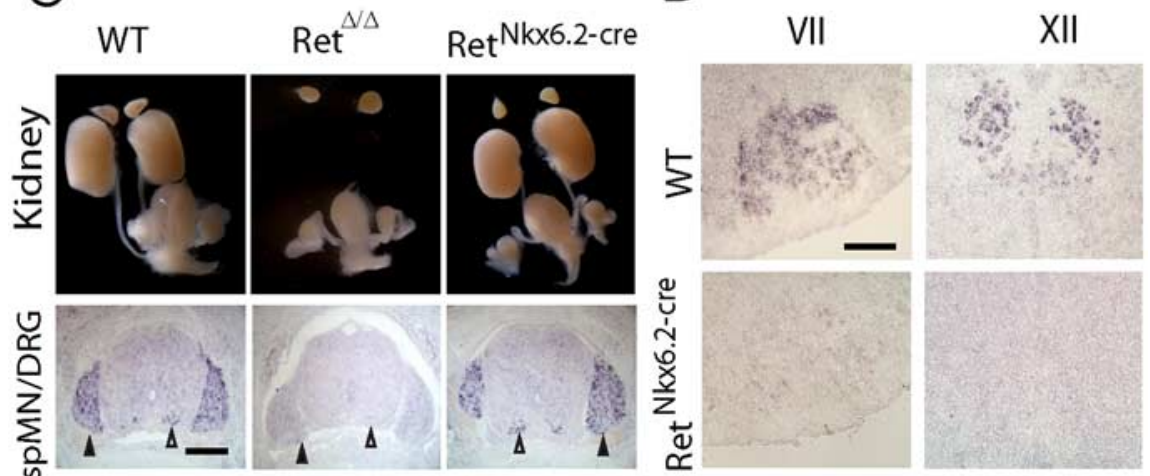

$\sum_{\substack{0 \\ \text { no }}}^{\substack{n \\ \mathrm{E}}}$

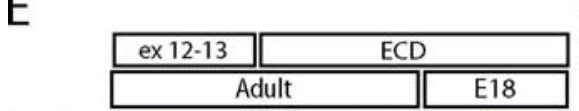

$\mathrm{F}$

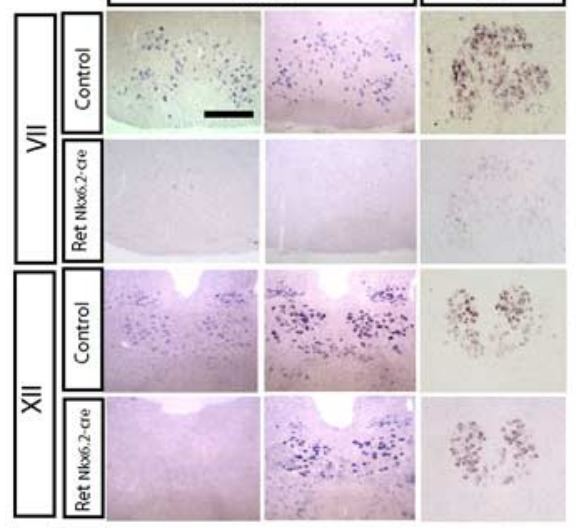

\section{(1)}
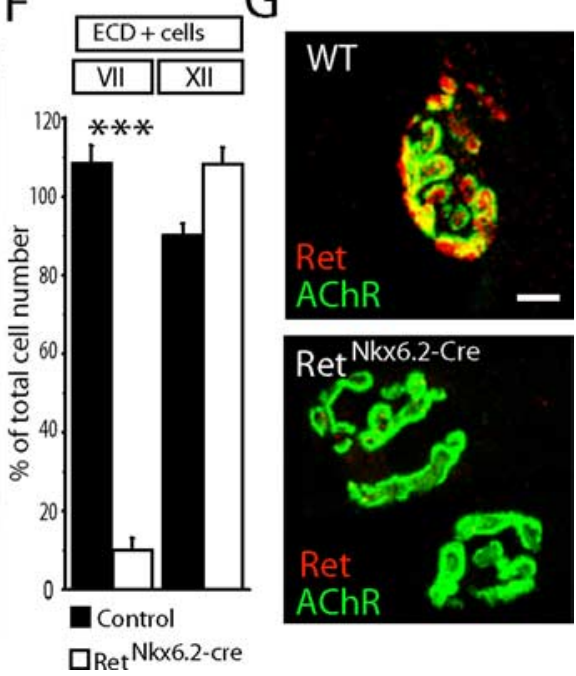

Figure 2. Conditional inactivation of Ret in cranial motor neurons. $A$, Strategy for producing a conditional Ret allele with schematic representation of the wild-type Ret locus and the targeting vector. The black rectangles represent exons, and the gray triangles represent Frt sites. LoxP (IX) sites are indicated by arrows. The targeting vector, a $12 \mathrm{~kb}$ Hind III(H)/EcoRI(E) fragment from the mouse Ret gene contains exons 7-18. One loxP site was introduced in intron 11. The second loxP, inserted in intron 13, was directly followed by the selection cassette (Neo) flanked by Frt sites. B, Schematic representation of the strategy used to analyze homologous recombination by Southern blot and select the ES cell clones (Ret ${ }^{\text {flox-neo/+ }}$ ) for blastocyst injection. Digestion with $\mathrm{Xbal}$ ( $X$ ) generated a $12.5 \mathrm{~kb}$ band for the wild-type allele and a $9.8 \mathrm{~kb}$ band for the floxed allele using the external probe (ep) probe. The internal probe (ip) was used to discriminate ES cell clones in which the homologous recombination had occurred between the LoxP sites; expected sizes are indicated. Flp- and Cre-mediated excision was used to produce Ret ${ }^{\text {Nkx6.2-Cre }}$ and Ret $^{\Delta / \Delta}$ animals. Ret ${ }^{\Delta / \Delta}$ mice carry a deletion of exons 12 and 13 in all cells (germline mutation), whereas Ret ${ }^{\text {Nkx6.2-Cre }}$ mice carry this deletion only in cells expressing Nkx6.2. C, Genetic excision of Ret exons 12 and 13 analyzed in E18 embryos. Ret ${ }^{\Delta / \Delta}$ mice carrying a deletion of Ret in the germline displayed kidney agenesis and absence of Ret exons 12 and 13 expression in spinal cord motor neurons and dorsal root ganglion by in situ hybridization. Ret ${ }^{\text {Nkx6.2-Cre }}$ mice show an intact urogenital system and kidney, and Ret expression can be detected in spinal cord motor neurons (spMNs) (white arrowheads) and in the dorsal root ganglia (DRG) (black arrowheads). D, Ret ${ }^{\text {Nkx6.2-Cre }}$ mice show a specific loss of Ret exons 12 and 13 expression in the facial (VII) and hypoglossal (XII) MNs. $\boldsymbol{E}, \boldsymbol{F}$, Motor neuron-specific regulation of Ret expression in cranial nuclei VII and XII. $\boldsymbol{E}$, In situ hybridization using the ex 12-13 and ECD probes on coronal section of the brainstem for the indicated motor nuclei, ages, and genotypes. $\boldsymbol{F}$, Ret ECD expression in motor neurons as percentage of total cell number in adult animals. Note the dramatic and specific loss of Ret transcript expression in the facial (VII) but not hypoglossal (XII) nucleus. G, Complete loss of Ret protein at the neuromuscular

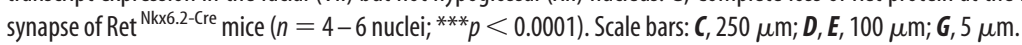



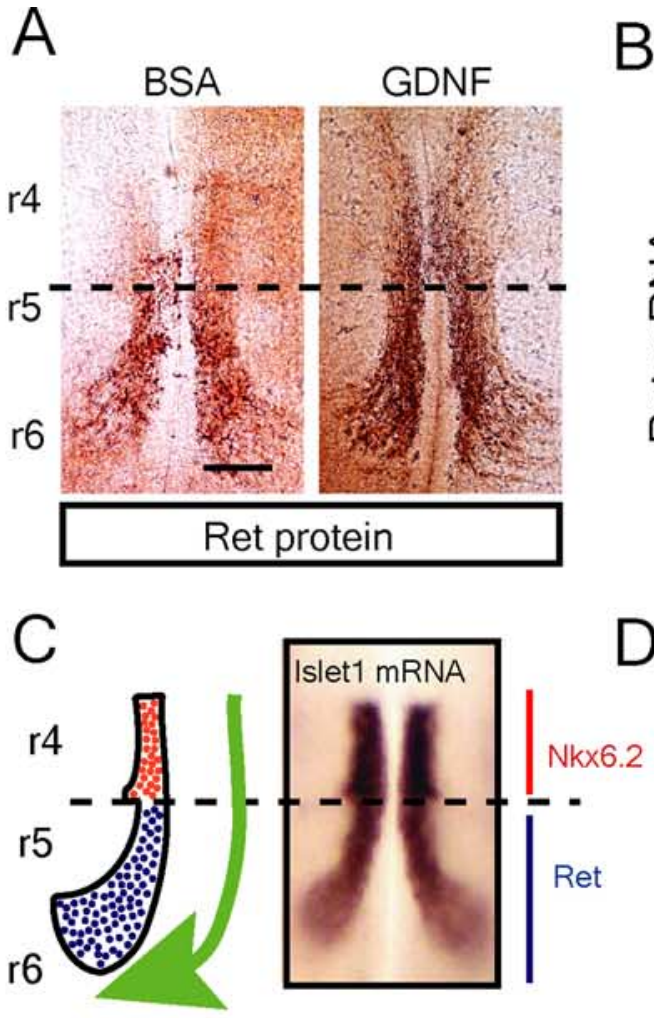

Rostro-caudal and dorso-ventral migration

E
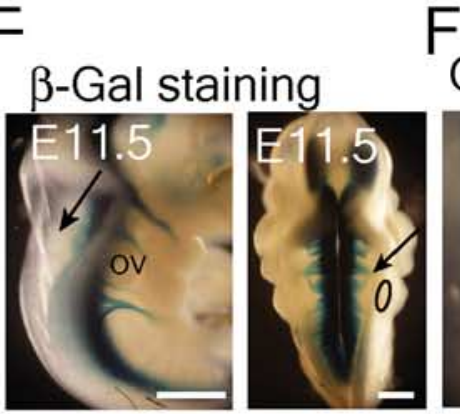

\section{GDNF mRNA}
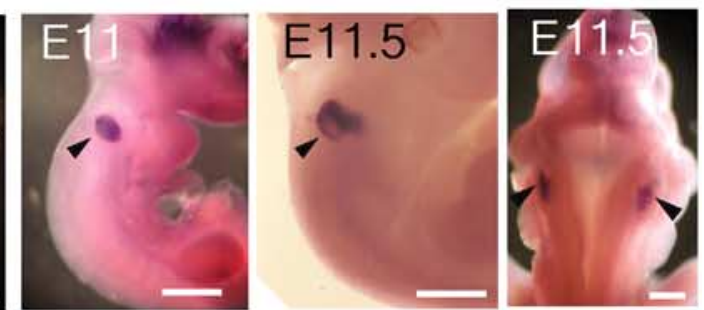

Nkx6.2+/lz mice

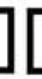

Control mice
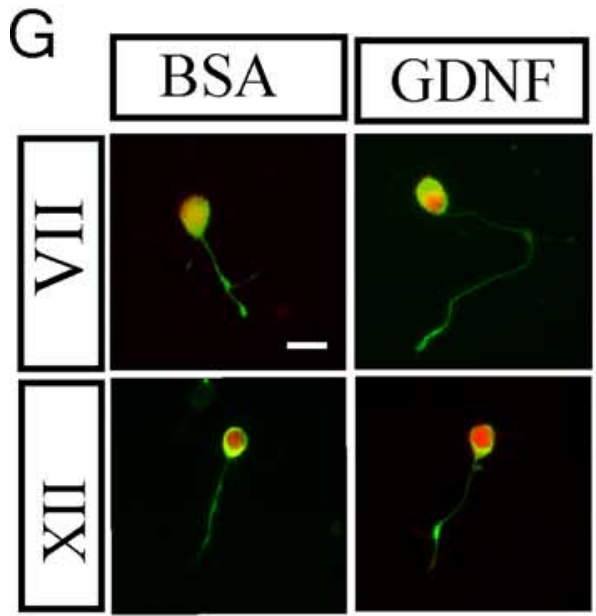

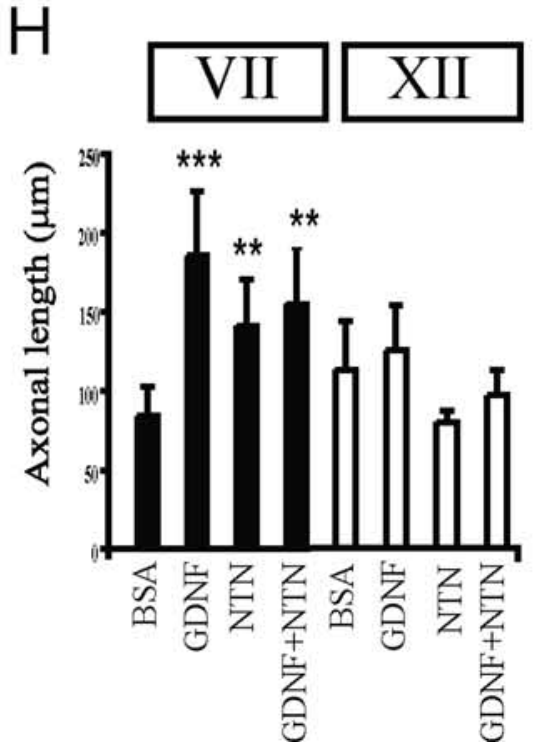

Such a transcript lacks the ATP binding domain, which is located in the deleted exon and is expected to produce a nonfunctional truncated (kinase dead) receptor because the resulting transcript is out of frame when splicing exon 11 to exon 14 . The ECD probe can therefore be used to monitor Ret expression in the absence of Ret signaling. Noteworthy, unlike the hypoglossal motor nucleus, expression from the Ret locus failed in the facial motor nucleus both at E18 and in the adult in the absence of Ret signaling (Fig. 2E,F). This suggests that Ret expression is induced by Ret signaling in facial but not hypoglossal motor neurons. A successful elimination of Ret protein at the neuromuscular synapse was confirmed. Whereas wild-type mice contained abundant Ret protein, Ret $^{\text {Nkx6.2-cre }}$ mice displayed a complete loss of Ret immunoreactivity at the neuromuscular synapse (Fig. 2G).

$\leftarrow$

Figure 3. Ret activated Ret expression and Ret induced axonal growth in facial but not hypoglossal motor neurons. $A$, GDNF (50 ng/ml) upregulated Ret protein expression in organotypic culture of E11.5 hindbrains [rhombomere 4-6 (r4 r6)] after $6 \mathrm{~h}$ compared with BSA-treated control. Wholemount immunostaining with Ret antibody on the control samples shows Ret expression restricted to migratory and postmigratory motoneurons (r5-r6, limited by dashed lines). GDNF induces increased expression of Ret in migrating motor neurons ( $(\mathrm{r} 5-\mathrm{r} 6$ ) as well as a precocious expression by premigatory motoneurons (r4). B, GDNF upregulated Ret mRNA expression in organotypic culture of E11.5 hindbrains [rhombomere 4-6 (r4-r6)] after $6 \mathrm{~h}$ compared with BSA-treated control (RT - , reaction without reverse transcriptase). Quantitative real-time $P C R$ was conducted for ret mRNA (mean \pm SEM of 3 independent experiments). $C$, Schematic illustration and islet 1 in situ hybridization of an open-book preparation of hindbrain showing the path of facial motor neuron migration. Premigratory (red) cells express Nkx6.2, whereas migrating and postmigratory cells express Ret (blue) (Vallstedt et al., 2001). D, Islet1 staining revealing that elimination of Ret as detected in Ret ${ }^{\text {Nkx.2-Cre }}$ mice did not affect cell migration. $\boldsymbol{E}-\boldsymbol{H}, \mathrm{GDNF}$ is expressed along the axonal pathway of the facial nerve and promotes axonal growth of facial but not hypoglossal motoneurons in primary culture. $\boldsymbol{E}$, The facial nerve exits the hindbrain at the level of the otic vesicle (arrows) as shown by the lateral (left) and dorsal (right) view of E11.5

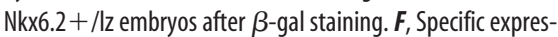
sion of GDNF mRNA in the otic vesicle of wild-type E11 and E11.5 embryos (black arrowheads) as shown by in situ hybridization. $\boldsymbol{G}, \boldsymbol{H}$, Axonal growth of facial but not hypoglossal motor neurons is affected by GDNF and NTN. G, Facial and hypoglossal motoneurons from E11.5 wild-type embryos were cultured in the presence of BSA or $50 \mathrm{ng} / \mathrm{ml}$ GDNF and stained for peripherin (green) and Islet1 (red) and the length of the axons measured. $\boldsymbol{H}$, Quantification of axonal length in the presence of BSA or $50 \mathrm{ng} / \mathrm{ml}$ neurotrophic factors (GDNF, NTN, and GDNF plus NTN) in primary culture of facial and hypoglossal motor neurons $(n=50-100)$. Graphs represent the mean \pm SEM. ${ }^{*} p \leq 0.05 ;{ }^{* *} p \leq 0.005 ;{ }^{* * *} p \leq 0.0005$. Scale bars: $\boldsymbol{A}, 100 \mu \mathrm{m} ; \boldsymbol{E}, \boldsymbol{F}, 250 \mu \mathrm{m} ; \boldsymbol{H}, 20 \mu \mathrm{m}$. 


\section{Early role of Ret for hindbrain motor neurons}

The Ret-induced Ret expression in facial motor neurons suggested that onset of expression during development is induced by a Ret ligand. To directly address whether GDNF can induce Ret expression in the facial motor nucleus, E11.5 organotypic hindbrain cultures were established from wild-type mice and treated with GDNF for $6 \mathrm{~h}$. The explants were either immunohistochemically stained for Ret in an open-book preparation or rhombomeres 4-6 were dissected out for RNA purification and quantitative PCR (Q-PCR). In control cultures receiving BSA instead of GDNF, Ret was expressed in migratory and postmigratory facial motor neurons (Fig. $3 A, C$ ), consistent with our previous results (Mikaels et al., 2000). GDNF treatment led to a rapid induction of Ret immunoreactivity in the migrating facial motor neurons as well as a precocious expression of Ret in premigratory facial motor neurons that normally do not express Ret (Fig. 3A). Q-PCR confirmed a markedly increased Ret mRNA expression in rhombomere 4-6 explants after GDNF stimulation for $6 \mathrm{~h}$ (Fig. $3 B)$. Facial motor neurons emerge at rhombomere 4 and migrate rostrocaudally and dorsoventrally to form the facial motor nucleus with Ret expression initiating at the time of migration (Fig. $3 C)$. Motor neuron migration was not affected in Ret $^{\text {Nkx6.2-cre }}$ mice (Fig. 3D).

Axonal growth and nerve exit from the neural tube occur concomitant with the migration of the cell somata (Garel et al., 2000). At E11.5, the facial nerve projections with exit points rostral to the otic vesicle were seen in Nkx6.2 $2^{+/ 1 z}$ mice (Fig. $3 E$ ). $\beta$-Galactosidase staining of these mice detects specifically cranial motor neurons and their axonal projections (Vallstedt et al., 2001). In situ hybridization for GDNF at E11.5 revealed GDNF expression in the otic vesicle, closely associated with the exit point and initial trajectory of the facial nerve (Fig. $3 F$ ), and could, thus, represent the endogenous source of Ret ligand regulating Ret expression in early facial motor neurons. GDNF was not expressed at the exit point or along the path of the hypoglossal nerve (Fig. $3 F$ ). Neurite outgrowth of dissociated E11.5 facial and hypoglossal motor neurons in response to GDNF for $6 \mathrm{~h}$ was studied in hindbrain cultures. Facial but not hypoglossal motor neurons showed significantly increased axonal length in response to GDNF and NTN, and the effects were not additive when GDNF and NTN were administered together (Fig. 3G,H). The GDNFinduced axonal growth of facial motor neurons was dependent on Ret, because the effect was missing in facial motor neurons from $\operatorname{Ret}^{\Delta / \Delta}$ mice (supplemental Fig. 1, available at www. jneurosci.org as supplemental material).

\section{Ret-dependent survival of motor neurons during development and regeneration}

We next examined the role of Ret for motor neuron survival. Facial and hypoglossal motor neuron numbers were quantified at E18 and in the adult Ret ${ }^{\mathrm{Nkx6} 6 \text {-cre }}$ mice. Facial motor nucleus displayed a $22 \%$ decrease at E18 and $37 \%$ in the adult, whereas the hypoglossal motor nucleus showed $20 \%$ reduction at E18 and $42 \%$ in the adult (Fig. $4 A$ ). The survival of adult regenerating axotomized facial motor neurons was examined in wild-type and Ret $^{\text {Nkx6.2-cre }}$ mice. Almost twice as many regenerating motor neurons were lost in the absence of Ret in the facial nucleus (Fig. $4 B, D)$. In contrast, no additional loss was seen in hypoglossal motor nucleus after axotomy (Fig. 4C,D). Thus, Ret is necessary for motor neuron survival both during embryogenesis as well as postnatally in both the facial and the hypoglossal motor nuclei. Ret is also supporting motor neuron survival of regenerating facial but not hypoglossal motor neurons.
Ret signaling and development of the neuromuscular synapse We addressed whether Ret, localized to the neuromuscular synapse, is acting as a retrograde signal for neuromuscular synapse maturation. Deficits in presynaptic maturation are manifested in a reduction of synaptic vesicle density and a decrease of the postsynaptic membrane covered by nerve terminals, which can be determined by synaptophysin immunohistochemistry (Fox et al., 2007). Neuromuscular synapses in the tongue were analyzed by several markers of the postsynaptic and presynaptic elements. Postsynaptic aggregation of AChR was visualized by the binding of fluorescently conjugated $\alpha$-bungarotoxin. Synapsin I and synaptophysin immunohistochemistry were used to detect components of the synaptic vesicles of the presynaptic specialization. Some sections were also stained for neurofilament to detect motor nerve projections to the muscle (Fig. $5 A$ ). At early postnatal stages AChR distribution at junctions are oval "plaque"-like receptor insertions with less clear boundaries that lack distinct outlines and any segregation of the synaptic zone into AChR-rich and AChR-poor regions. Maturation involves first a reduction in synaptic size and the emergence of streaks of more intense labeling within the synapse, which during the following weeks expand and develop into the highly branched localization of receptors in "pretzel-like" specialization (Slater, 1982a; Balice-Gordon and Lichtman, 1990, 1993). In E18 wild-type animals, postsynaptic specialization was seen by AChRs aggregated into streaks with clear receptor-rich and receptor-poor areas (Fig. 5A, arrowheads). In Ret ${ }^{\Delta / \Delta}$ mice, AChR clustering was markedly reduced with a lack of streaks of more intense specializations (Fig. $5 A$ ), and the overall size as measured by the area of AChRs was significantly larger than in wild-type mice $\left(928 \pm 195 \mu \mathrm{m}^{2}\right.$ in wildtype mice and $1396 \pm 184 \mathrm{um}^{2}$ in Ret $^{\Delta / \Delta}$ mice). However, quantification revealed that the overall amount of AchRs was similar between the different strains (Fig. 5C). Thus, a deficit of AChR clustering into rich and poor regions and the absence of synaptic area reduction show that postsynaptic maturation of neuromuscular synapses is impaired in the absence of Ret. Analysis of the presynaptic region of the neuromuscular junction indicated that the overall quantity of both synapsin I and synaptophysin immunoreactivity was significantly reduced in the $\operatorname{Ret}^{\Delta / \Delta}$ compared with the control mice (Fig. $5 A, C$ ). In addition, unlike wild-type neuromuscular synapses, synapses of Ret ${ }^{\Delta / \Delta}$ mice often showed nerve terminal sprouting (Fig. $5 A$, arrows). Similar terminal sprouts from intact nerve terminals have been observed in the adult partially denervated muscle (Brown et al., 1981).

The number of endplates was quantified in bungarotoxinlabeled serial sections of the E18 and adult tongues. At E18, a similar number was present in Ret ${ }^{\mathrm{Nk} 6.2 \text {-cre }}$ and in control mice $\left(72,927 \pm 1370\right.$ in control and 78,670 \pm 4200 in Ret ${ }^{\text {Nkx6.2-cre }}$ mice) (Fig. 5D). We next analyzed synapses in the adult where the number in control animals is expected to be similar as at E18 because synapse elimination is believed to be nearly complete already at the time of birth in tongue muscles (Yamane et al., 2001). Adult Ret ${ }^{\mathrm{Nkx} 6.2 \text {-cre }}$ mice had significantly fewer endplates than control mice (Fig. 5D) $(62,206 \pm 625$ synapses in adult Ret $^{\text {Nkx6.2-cre }}$ mice and 106,770 \pm 1053 in control mice). Because the tongue muscle is larger in adult than at E18, the sampling method introduces a common bias that prevents direct comparison between age groups. In the adult, the AChRs and synaptic vesicles as well as the branching and maturity of the synapses were similar between control and Ret ${ }^{\mathrm{Nkx6.2-cre}}$ mice and no significant differences were observed in the quantification of the presynaptic and postsynaptic compartments (Fig. $5 B-D$ ) (and summarizing illustration in Fig. $5 E$ ). We found that all AChR-positive end- 

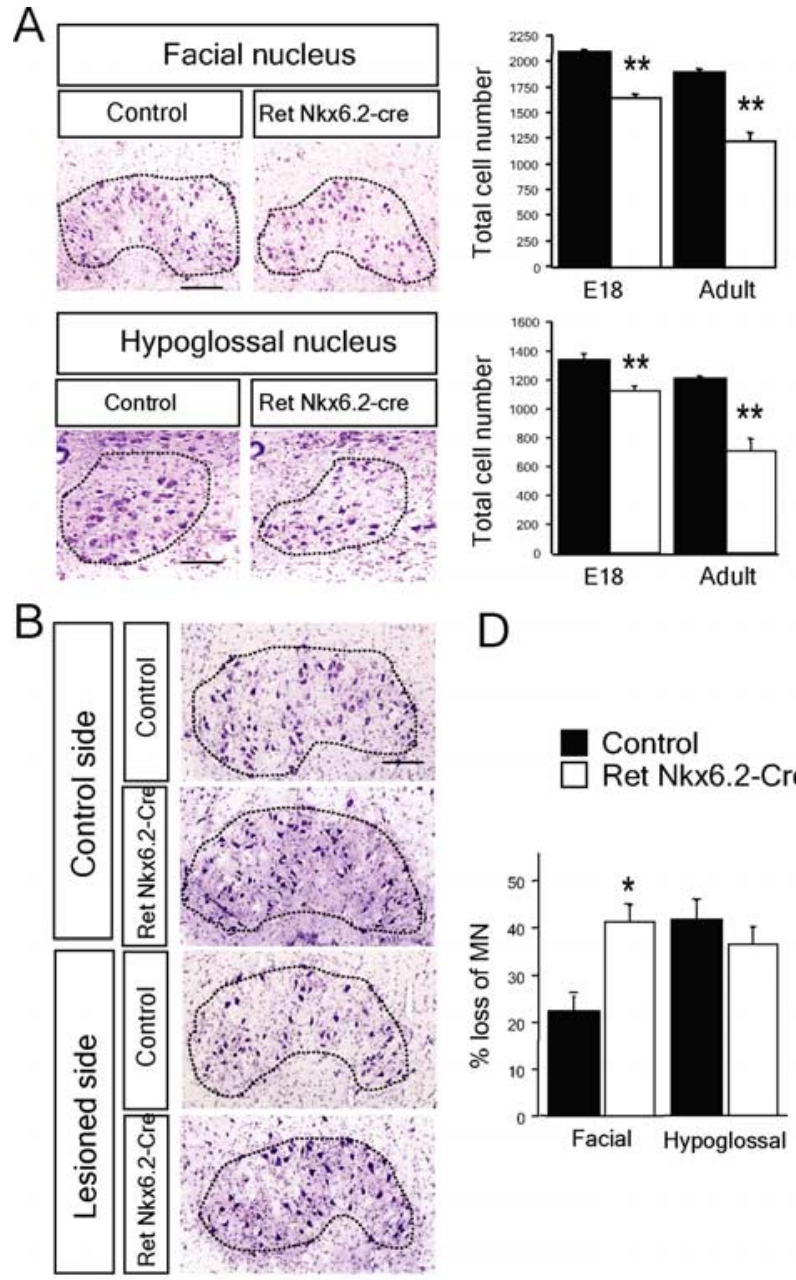

D
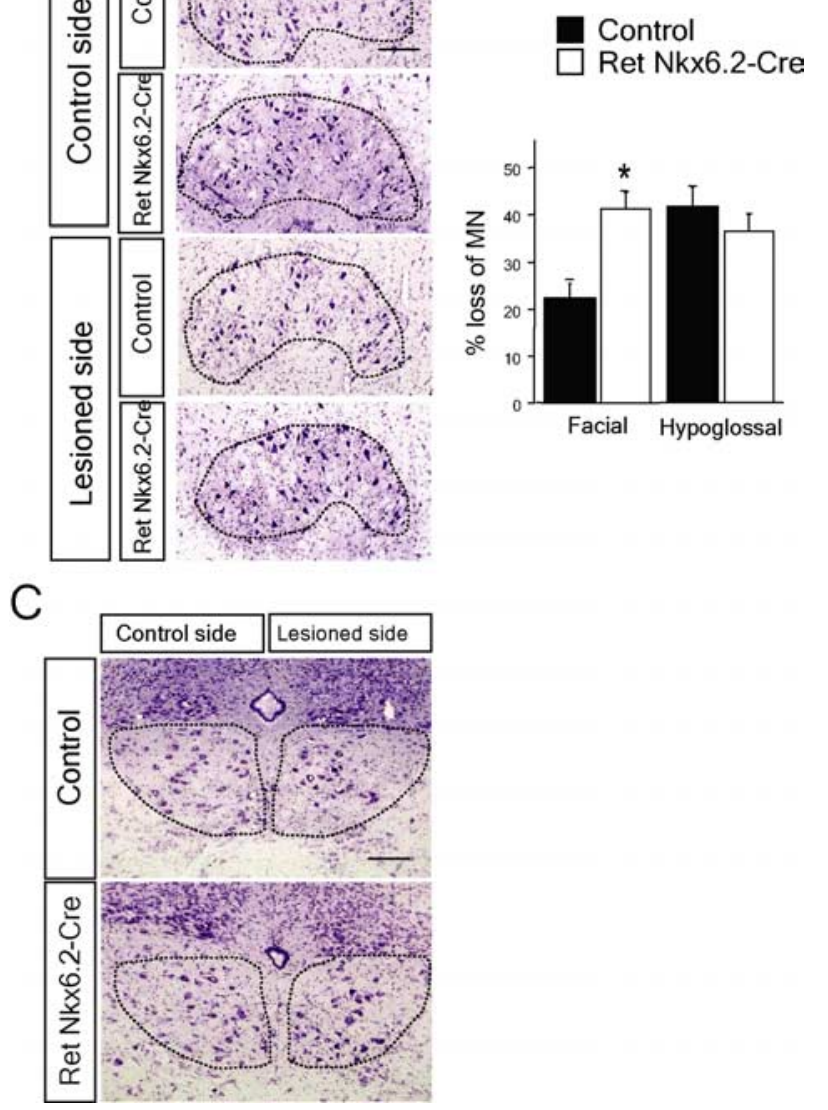

Figure 4. Postnatal motor neuron death in the absence of Ret. $A$, Motor neuron loss in facial and hypoglossal motor nuclei of adult Ret-deficient mice. Cresyl violet staining of coronal sections of facial and hypoglossal nuclei and graph showing the total number of motoneurons in

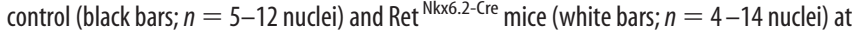
E18 and 3-4 months (adult). Nuclei are outlined by the dashed lines. Graphs represent the mean \pm SEM. All the groups were statistically significant from controls; ${ }^{* *} p \leq 0.005 . \boldsymbol{B}-\boldsymbol{D}$, Ret inactivation decreases the survival of facial but not hypoglossal adult motor neurons $21 \mathrm{~d}$ after nerve lesion. $\boldsymbol{B}$, Photomicrographs of cresyl violet staining of the right facial nucleus (control side) and the left facial nucleus (lesioned side) from control and Ret ${ }^{\mathrm{Nkx6.2} \text {-Cre }}$ mice, as indicated. The dashed line represents the limit of the nucleus. C, Photomicrographs of sections showing the right hypoglossal nucleus (control side) and the left hypoglossal nucleus (lesioned side) from control and Ret ${ }^{\mathrm{Nkx} 6.2-\mathrm{Cre}}$ mice, as indicated. The dashed lines delimit the nucleus. D, Quantification of facial and hypoglossal motor neuron loss by the lesion as percentage of the control side in control mice (control, $n=3$ mice; Ret ${ }^{\mathrm{Nkx} 6.2 \text {-Cre }}, n=9$ mice). Note the significant loss of facial but not hypoglossal MN as a consequence of the Ret genomic inactivation $\left({ }^{*} p<0.015\right)$. Scale bars, $100 \mu \mathrm{m}$. plates also contained synaptophysin immunoreactivity at both stages in control and Ret ${ }^{\text {Nkx6.2-cre }}$ mice $(n=60-100$ synapses analyzed per genotype and age condition), suggesting that all remaining endplates in adult Ret-deficient mice are innervated.

Because there seems to be different requirements of Ret activation for Ret expression between facial and hypoglossal motor neurons, we were interested to examine whether the presynaptic role of Ret for maturation was also seen in other cranial motor neuron muscle targets (Fig. 6). The synapses of the oculomotor extraocular medial rectus muscle were less mature than synapses in the tongue of E18 control mice, with less synaptic vesicles as revealed by weaker synaptophysin staining. In Ret ${ }^{\Delta / \Delta}$ mice, the synaptophysin intensity was significantly reduced ( $18.6 \%$ reduction compared with control; $p=0.022$ ) (Fig. 6) and the synapse area was significantly larger $\left(2417 \pm 597 \mathrm{vs} 3167 \pm 821 \mu \mathrm{m}^{2}\right.$, control and Ret ${ }^{\mathrm{Nkx6} 6.2 \text {-cre }}$, respectively; $p=0.008$ ). In the buccinator muscle receiving innervation from the bucal branch of the facial nerve, the reduction of synaptophysin immunoreactivity was even more pronounced than in oculomotor and hypoglossal synapses (65.9\% reduction vs control; $p \leq 0.0005)$. Furthermore, facial motor neuron synapses displayed a loss of AChRs postsynaptically (22.2\% of loss; $p \leq 0.005)$. The size of the facial nerve synapse area was significantly reduced compared with control mice (2245 \pm 564 vs $1764 \pm 171 \mu \mathrm{m}^{2}$, control and Ret ${ }^{\mathrm{Nkx6} .2 \text {-cre }}$, respectively; $p=0.040$ ). These results show that there is a requirement of Ret for presynaptic maturation in several muscles innervated by different motor neuron nuclei, consistent with the expression of Ret in all cranial motor nuclei (Mikaels et al., 2000). However, the most affected synapses were those from the facial nerve, which also displayed a Ret-dependent Ret expression and required Ret for cell survival in the adult during regeneration.

\section{Ret signaling in the adult regenerating} neuromuscular synapse

The previous data established a role for Ret signaling in the maturation of the neuromuscular synapse during development. We examined whether Ret signaling also is essential for the formation of new synapses in the adult after nerve lesion. The hypoglossal nerve was transected and reinnervation as well as neuromuscular synapses was analyzed 3 weeks later. In lesioned control mice, neurofilament immunostaining showed the presence of regenerated nerve fibers (Fig. 7A), similar to unlesioned controls (Fig. $7 A$ ), and an establishment of new synaptic contacts as a result of reinnervation (Fig. 7A). The size of the neuromuscular synapses appeared significantly smaller than in the contralateral unlesioned side (Fig. 7A) correlating with AchR distribution conforming precisely to the shape of the reinnervating nerve terminal, similar to what was described previously (Rich and Lichtman, 1989). Aggregates of postsynaptic AchRs are maintained for long periods of time in the absence of nerve innervation (Slater, 1982b; Rich and Lichtman, 1989) and are reoccupied by reinnervating nerves (Letinsky et al., 1976). In Ret ${ }^{\text {Nkx6.2-cre }}$ mice, neurofilament-positive nerve fibers reinnervating the muscle on the lesioned side were similar to control lesioned mice (Fig. $7 A)$. Quantification of the volume occupied by the regrowing neurofilament-positive nerve fibers showed no difference between control mice and Ret ${ }^{\mathrm{Nkx} 6.2 \text {-cre }}$, suggesting an equal reinnervation in both genotypes (Fig. 7C). The size of the AChR postsynaptic membrane was larger in the reinnervated synapses of the Ret $^{\text {Nkx6.2-cre }}$ mice compared with wild-type mice $(1890 \pm 235$ $\mu \mathrm{m}^{2}$ in wild-type vs $2263 \pm 78.8 \mu \mathrm{m}^{2}$ in Ret ${ }^{\text {Nkx6.2-cre }}$ mice; $p \leq$ 0.05 ) with more diffuse AChR localizations within the specialization. Quantification of the synaptic markers showed a reduction 
of $20 \%$ of AChRs, $71.6 \%$ of synapsin 1, and $65.5 \%$ synaptophysin in lesioned Ret $^{\text {Nkx6.2-cre }}$ mice compared with the lesioned side of control mice (Fig. $7 A, B$ ). The marked reduction of both synapsin I and synaptophysin represents an overall loss in most or all synapses (Fig. 7A,B), because measurement of the number of endplates containing any staining for presynaptic markers was similar between lesioned control and Ret ${ }^{\text {Nkx6.2-cre }}$ mice (percent endplates containing any synaptophysin staining: control, $62.5 \pm$ 6.5\%; Ret $^{\text {Nkx6.2-cre }}$ mice, $50.1 \pm 7.8 \%$; $n=$ 81 and 89 , respectively; similar results were obtained for synapsin I staining: control,

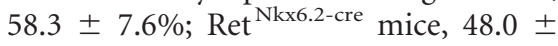
$2.6 \% ; n=97$ and 106, respectively). This suggests that Ret is important for presynaptic maturation but not for axonal regeneration. Another presynaptic marker, anchored in the cytosolic face of the membrane, Snap-25, confirmed an impairment of mature nerve terminals at the site of AChR specializations in the Ret $^{\mathrm{Nkx6.2-cre}}$ mice after regeneration (supplemental Fig. 2, available at www. jneurosci.org as supplemental material). Combined, our data show that Ret is important for presynaptic maturation but appears not to be essential for regeneration and initial axon contact with the postsynaptic membrane.

Hypoglossal nerve lesion did not cause any excessive cell death in the hypoglossal nucleus as a consequence of an absence of Ret (Fig. $4 C, D$ ). The number of AChRpositive localizations in the control and Ret $^{\text {Nkx6.2-cre }}$ mice after nerve lesion was counted. Because lesions were performed unilaterally, numbers were established in the experimental one-half of the tongue. In control mice, the number of AChR specializations was not reduced at 3 weeks after lesion compared with control, unlesioned muscles (Fig. 7D). In agreement with our previous results, the unlesioned side of the Ret ${ }^{\text {Nkx6.2-cre }}$ mice displayed a significantly reduced number compared with control mice but lesioning did not reduce this further (Fig. 7D). Thus, an absence of Ret does not have any effect on endplate numbers during reinnervation. Figure $7 E$ summarizes the phenotype of Ret $^{\mathrm{Nkx6.2-cre}}$ mice during reinnervation in the adult.

\section{Discussion}

The present study was conducted to elucidate whether Ret signaling is required for maturation of the neuromuscular synapse. We report that Ret receptors are concentrated in nerve endings at the presynaptic

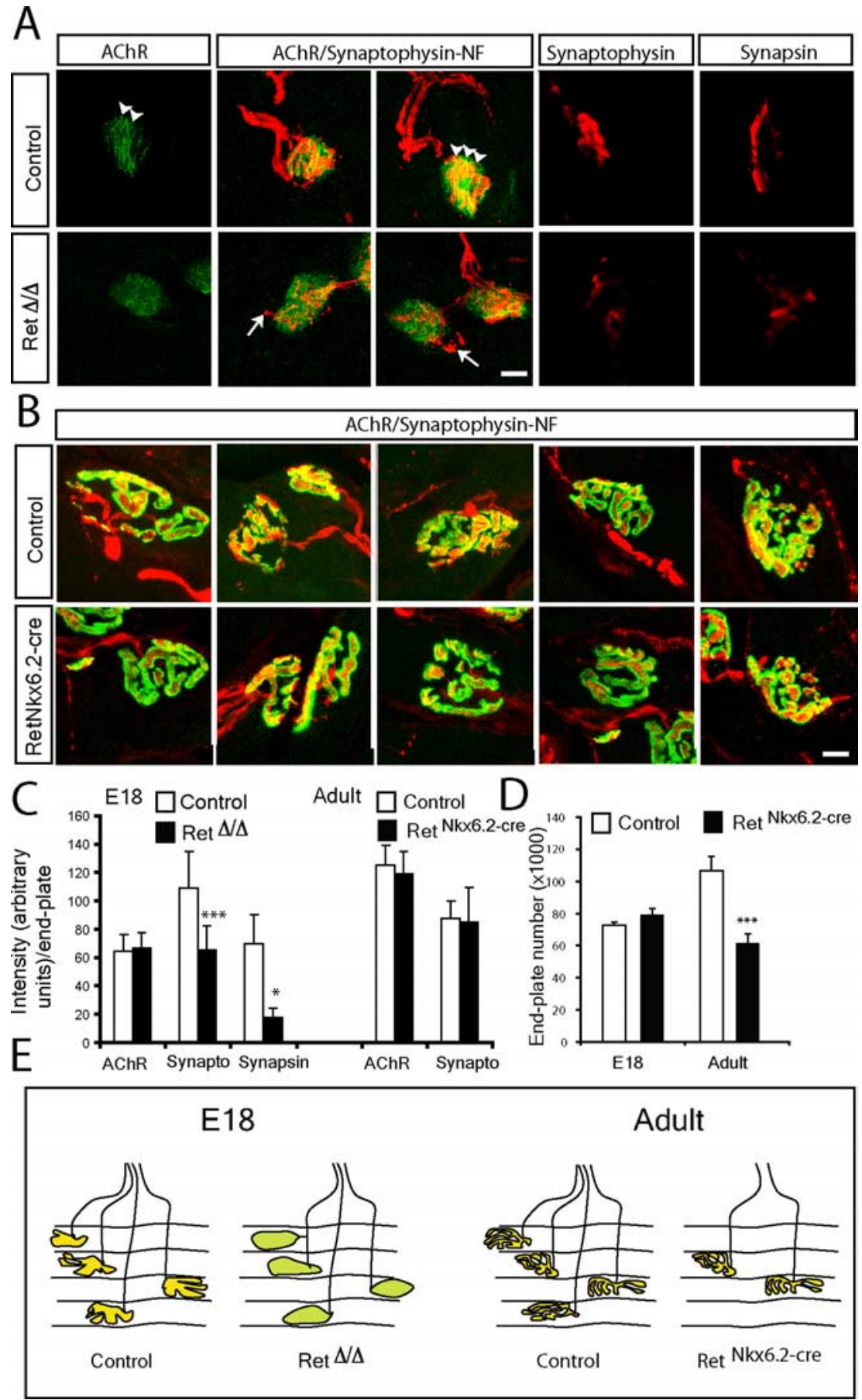

Figure 5. Deficits of synapse maturation in the absence of Ret signaling. $\boldsymbol{A}, \boldsymbol{B}$, Photomicrographs of neuromuscular synapses in the E18 $(\boldsymbol{A})$ and adult $(\boldsymbol{B})$ tongue of control and the Ret-deficient mice (Ret ${ }^{\Delta / \Delta}$ in $\boldsymbol{A}$ and $\operatorname{Ret}^{\mathrm{Nkx6} 2 \text {-Cre }}$ in $\boldsymbol{B}$ ). The presynaptic region was stained by synapsin I or synaptophysin immunohistochemistry (red, as indicated). AChRs in the postsynaptic membrane were labeled by fluorescent coupled bungarotoxin binding (green). Neuromuscular junctions visualized by a triple staining that combined synaptophysinneurofilament (synaptophysin-NF; red) with bungarotoxin binding (AChR; green) are indicated. In $A$, note the reduction in the immunostaining of presynaptic components (synapsin l and synaptophysin) in Ret-deficient mice. The postsynaptic AChRs are more aggregated in control than Ret ${ }^{\Delta / \Delta}$ mice atE18 (arrowheads). Also note terminal sprouts in Ret ${ }^{\Delta / \Delta}$ mice (arrows in $A$ ), whereas general morphology of both presynaptic and postsynaptic elements of the neuromuscular junction is similar between adult control and Ret ${ }^{\text {Nkx6.2-Cre }}$ mice (B).C, Quantification of synaptophysin (synapto) and synapsin immunoreactivity as a measure of synapse maturations at the neuromuscular synapse and AChRs staining intensity atE18and in adult mice. Note the significant loss of synaptophysin and synapsin but not postsynaptic AChRs in the absence of Ret signaling at E18. No significant difference was found in adult mice. D, Quantification of the total number of AChR containing endplates in serial sections through the entire tongue at E18 and in the adult of both genotypes. Note a significant reduction of the total number of endplates in adult Ret ${ }^{\mathrm{Nkx6.2-Cre}}$ mice. $\boldsymbol{E}$, Schematic illustration summarizing our interpretation of the results from the above studies depicting vesicle containing presynaptic terminals overlaying the postsynaptic AChR membrane in control mice (yellow). In E18 Ret ${ }^{\Delta / \Delta}$ mice, synapses are less developed (green) but in similar number as in control embryos. Adult Ret ${ }^{\mathrm{Nkx6.2-Cre}}$ mice display a reduced number of synapses, which otherwise appear normal. Graphs represent the mean \pm SEM. ${ }^{* * *} p \leq 0.005$; ${ }^{*} p \leq$ 0.05. Scale bars, $10 \mu \mathrm{m}$. 
A
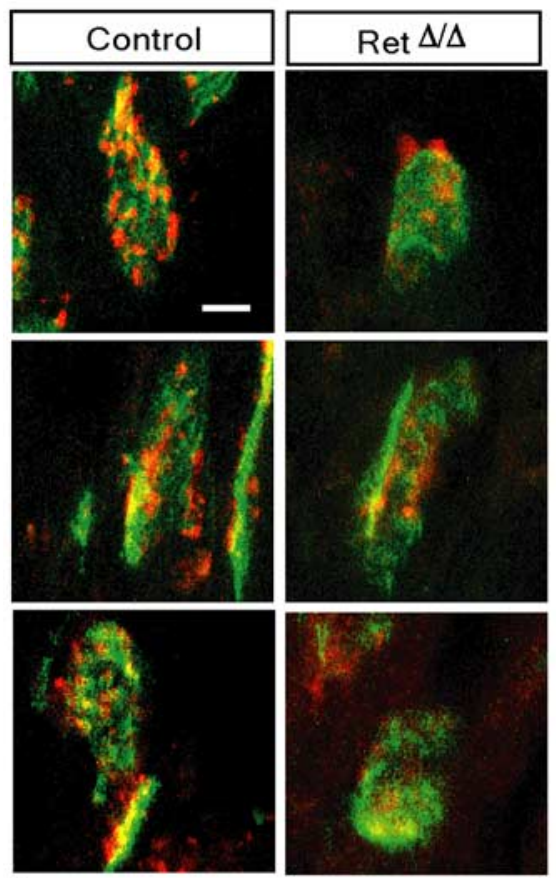

Oculomotor nerve synapses
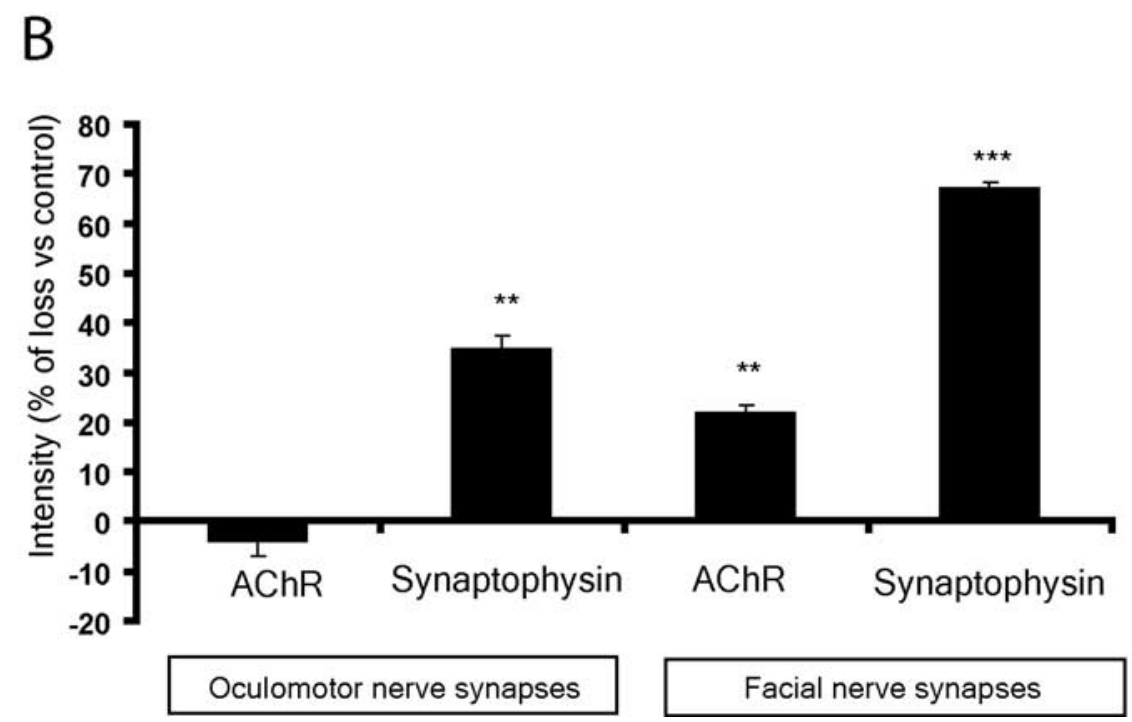

Figure 6. Developmental deficit of synapse maturation in the absence of Ret signaling in facial and oculomotor nerve synapses. $\boldsymbol{A}$, Photomicrographs of neuromuscular synapses in the E18 facial and oculomotor and muscles. The nerve and presynaptic region was stained by synaptophysin and neurofilament immunohistochemistry (red) and AChRs in the postsynaptic membrane by fluorescent-coupled bungarotoxin binding (green). Note similar deficits of synapse maturation in these muscles as in the tongue of Ret ${ }^{\Delta / \Delta}$ mice. $B$, Quantification of AChR and synaptophysin immunoreactivity at the neuromuscular synapse. Note deficits in synaptophysin immunoreactivity in Ret ${ }^{\Delta / \Delta}$ mice of both muscles, with a more pronounced deficit in the facial nerve synapses. Also note loss of AChR in the buccinator but not oculomotor muscle. Graphs represent the mean \pm SEM. ${ }^{*} p \leq 0.05 ;{ }^{* *} p \leq 0.005$; ${ }^{* * *} p \leq 0.0005$. Scale bar, $10 \mu \mathrm{m}$.

compartment of the synapses, whereas Ret ligands are expressed in the target tissue. In early development, Ret signaling reinforces additional Ret expression in facial but not hypoglossal neurons, whereas motor neuron survival embryonically as well as postnatally is compromised in both facial and hypoglossal motor nuclei in Ret-null and conditionally null mutant mice. Our findings also show that Ret-deficient motor neurons display deficits in presyn- aptic maturation during development. A large number of endplates are lost postnatally in the absence of Ret, but those that form appear normal in the adult mouse. Maturation of the adult reinnervated nerve endings is severely compromised when Ret signaling is abolished. This set of results provides evidence that Ret is physiologically important postnatally for both motor neuron survival and establishment of the neuromuscular synapse. Based on our results, we propose a model in which Ret could play a function in the presynaptic and postsynaptic coordination of the developing neuromuscular synapse. Ret activation by ligands released from the muscle and/or terminal Schwann cells promotes presynaptic maturation, which indirectly also can have effects on the postsynaptic organization (Fig. 7F). Albeit Ret clearly is important, the development of many synapses in its absence underscores the presence of other synaptic organizers during development, such as FGFs (Fox et al., 2007).

\section{Early roles of Ret}

Our data provide evidence for a selective role of Ret for axonal growth of facial but not hypoglossal motor neurons at early embryonic stages. It is intriguing that the differential biological effect of Ret activation between these classes of motor neurons corresponded with a Ret-dependent Ret expression in facial but not hypoglossal motor neurons. In our experiments, addition of Ret ligand even resulted in a precocious Ret expression in premigratory facial motor neurons. We also identified a source of GDNF expression in the otic vesicle at the time of Ret induction in the migrating facial motor neurons, which coincides with facial nerve exit [Fig. $3 E, F$ (Garel et al., 2000)], whereas GDNF expression was not seen at the exit zone of the hypoglossal nerve. The temporal coincidence of facial nerve exit with GDNF expression at the exit position indicates this ligand as the endogenous source inducing Ret expression in migratory facial motor neurons. The identification of a ligandinduced expression of its own receptor suggests an autoregulatory loop in which the growing nerve fibers receiving ligand acquires an increased response. Our data are interesting in light of a recent study showing a nerve growth factor (NGF)-dependent expression of Ret and its coreceptors in sensory neurons during development. This dependency for onset of expression was evident only in one sensory subpopulation expressing Ret [i.e., Ret expressing $\mathrm{TrkA}^{+}$small size nociceptive neurons but not in the large size Ret $^{+}$neurons (Luo et al., 2007)]. Although initial expression is NGF dependent, maintenance of coreceptor expression at post- 
natal stages was found to be autoregulated by Ret (Luo et al., 2007). It is conceivable that Ret itself also is autoregulated in sensory neurons, similar to our findings in facial motor neurons. Because Ret expression underlies several aspects of the diversification of nociceptive neurons into two different classes, the peptidergic and nonpeptidergic nociceptors shortly after birth (Molliver et al., 1997) by regulating expression of channels determining the receptor properties of these cells (Luo et al., 2007), a putative autoregulation of Ret suggests a role in reinforcing plasticity of cellular function during normal somatosensory perception, as well as during chronic pain. As we learn more about the diversity between motor neuron subtypes, our results on the facial and hypoglossal motor neurons, which raise parallels to the sensory nervous system, encourage future studies on Ret functions in motor neuron subtypes.

\section{Motor neuron survival by GDNF family} ligand signaling via Ret

A large proportion of motor neurons initially generated during development are lost by naturally occurring cell death (Hamburger, 1975). Despite that GDNF is the most potent motor neurotrophic factor (Henderson et al., 1994; Oppenheim et al., 1995), the role of GDNF and the other GDNF family members for motor neuron survival postnatally and in adulthood has not been addressed in vivo. Ret-null mutant mice die at birth, but the conditional elimination of Ret specifically in cranial motor neurons allowed the mice to survive into adulthood in our experiments. Because of this, we could determine its role for motor neuron survival in the postnatal animal.

Mice lacking GDNF and GDNF family receptor $\alpha 1$ (GFR $\alpha 1)$ display a loss of close to $20 \%$ of trigeminal, hypoglossal, facial, and spinal lumbar motor neurons at birth (Moore et al., 1996; Sanchez et al., 1996; Cacalano et al., 1998; Mikaels et al., 2000; Oppenheim et al., 2000). Mice lacking NTN or GFR $\alpha 2$, the NTN binding receptor, do not have any clear loss of motor neurons (Heuckeroth et al., 1999; Rossi et al., 1999; Garces et al., 2000), and a third coreceptor, GFR $\alpha 3$, is not expressed in embryonic motor neurons (Mikaels et al., 2000). Although GDNF can signal independently of Ret, via GFR $\alpha 1$ as well as by the neural cell adhesion molecule NCAM (Sariola and Saarma, 2003), the present study suggests that the effects on embryonic motor neuron survival determined in loss- and gain-offunction studies of GDNF in vivo are attributable to a Retdependent signaling.

Considerable evidence supports the idea that motor neurons depend on multiple neurotrophic factors produced by different
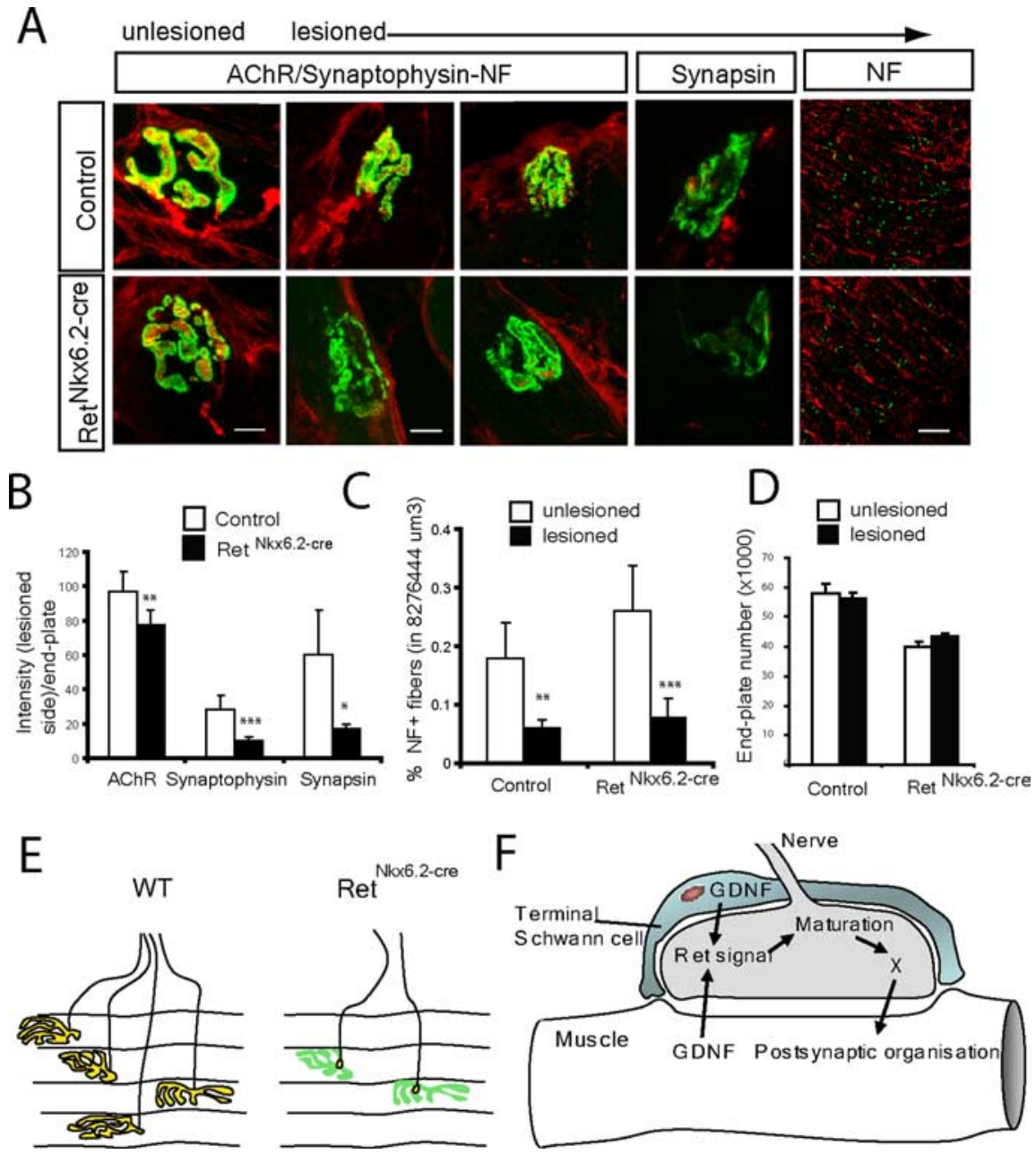

Figure 7. Requirement of Ret for maturation of regenerating neuromuscular synapses in the adult mouse. $\boldsymbol{A}-\boldsymbol{D}$, The hypoglossal nerve was lesioned and reinnervation of synaptic sites at the muscle examined 3 weeks later in the muscle. $\boldsymbol{A}$, Immunohistochemistry for neurofilament (NF) and synaptophysin immunohistochemistry (red) or synapsin I (red, where indicated) and AChRs (green), comparing tongue sections from the side where the hypoglossal nerve was lesioned and the contralateral unlesioned side, as indicated. After lesion, the neurofilament immunostaining shows that reinnervation occurs in the tongue of both control and mutant mice, but the establishment of the mature synaptic contact after reinnervation detected in control is absent in Ret $^{\mathrm{Nkx6.2-Cre}}$ mice. B, Quantification of AChRs, synaptophysin, and synapsin I intensity in control and reinnerverated muscles of Ret $^{\text {Nkx6.2-Cre }}$ mice versus control mice shows a strong reduction of all measured intensities. $\boldsymbol{C}$, Quantification neurofilament staining in a defined volume of each side of the tongue (unlesioned vs lesioned) for control and mutant mice. Note the reduction of NF staining on the lesioned site of the tongue both in control and Ret ${ }^{\mathrm{Nkx6.2-Cre}}$ mice. There was no statistical significance between control and Ret ${ }^{\mathrm{Nkx6} .2-\mathrm{Cre}}$ mice. $\boldsymbol{D}$, The number of postsynaptic endplates in one-half of the tongue (lesioned and unlesioned sides, as indicated) of control and Ret ${ }^{\mathrm{Nkx} 6.2-\mathrm{Cre}}$ mice. Note that the number of postsynaptic structures were not affected by Ret deletion. $\boldsymbol{E}$, Schematic illustration summarizing the results from the above studies. Although we find mature presynaptic terminals localizing with AChR-rich regions (yellow) in control animals 3 weeks after lesion, Ret ${ }^{\text {Nkx6.2-Cre }}$ mice show only punctuate presynaptic contact in all endplates (yellow) overlaying AChR postsynaptic organizations (green), but displaying severe deficits of presynaptic maturation. $\boldsymbol{F}$, Proposed model for Ret signaling in the establishment and maturation of the neuromuscular synapse. The solid arrows indicate processes with direct or indirect supporting data, and the dashed arrow indicates a suggestion that postsynaptic maturation may affect GDNF production/release and thereby also affect presynaptic maturation. ${ }^{* *} p \leq 0.005$; ${ }^{* * *} p \leq 0.0005$. Scale bars: NF, $100 \mu \mathrm{m}$; all other images, $10 \mu \mathrm{m}$.

cell types reflecting their location and peripheral targets for their survival. For instance, only limb innervating motor neurons can be rescued from cell death during development by hepatocyte growth factor (Yamamoto et al., 1997; Novak et al., 2000) and in the facial motor nucleus, GFR $\alpha 1$ and GFR $\alpha 2$ are expressed in distinct subpopulations that discriminate motor neuron pools during development (Mikaels et al., 2000). However, Ret is expressed in most or all neurons of the facial nucleus during development and is present in many cells also in the adult (Fig. 2) (Mikaels et al., 2000). This opens for the possibility that GDNF 
family ligands via Ret could be important for the survival of motor neurons by acting also after birth. Indeed, conditionally deleting Ret in cranial motor neurons led to an additional loss after birth in facial and hypoglossal motor neurons. Thus, we established that Ret signaling is required for motor neuron survival also postnatally, but this requirement may be unrelated to its importance for establishment of functional synapses, because mice without synaptogenesis do not show any excessive death of motor neurons (Terrado et al., 2001). Our data also conclusively show that not all motor neurons depend on Ret signaling for survival, because large numbers survived independently of Ret into adulthood.

Exogenous GDNF has a robust survival effect on axotomized facial motor neurons (Henderson et al., 1994; Zurn et al., 1994; Oppenheim et al., 1995; Yan et al., 1995) that most likely is a reflection of a physiological role of Ret activation for the survival of lesioned motor neurons, because our data show an excessive cell death in the axotomized Ret ${ }^{\mathrm{Nkx6.2-cre}}$ mice. This survival role of Ret signaling for damaged motor neurons was specific for this nucleus, because lesioned hypoglossal motor neurons were unaffected by the lack of Ret signaling. Ret (Fig. 2E) and GFR $\alpha 1$ (Glazner et al., 1998; Mikaels et al., 2000) are abundantly expressed in most neurons of both these nuclei, and Ret-deficient mice no longer express any active Ret receptors, so the differences in dependency does not reflect distinct expression and/or localization of the receptor as a consequence of the lesion. GDNF expressed in Schwann cells is rapidly upregulated after sciatic nerve lesion with peak levels at $7 \mathrm{~d}$ and soluble GFR $\alpha 1$ released from these cells may act on regenerating motor axons (Naveilhan et al., 1997; Fundin et al., 1999; Paratcha et al., 2001). It is conceivable that the additional neuronal loss in facial but not hypoglossal nuclei of Ret ${ }^{\mathrm{Nkx6.2-cre}}$ mice after lesion is a result of a greater supply of GDNF and cofactors in facial than hypoglossal regenerating nerves. It is intriguing that only $\sim 20 \%$ of motor neurons were lost in facial nucleus, whereas the hypoglossal nucleus displayed $>40 \%$ motor neuron loss in control animals. Hence, the conjecture of a differential supply of Ret ligands in different nerves would also explain the greater loss in the hypoglossal nucleus than facial nucleus of control animals. In all, our data support a view that Ret plays essential roles for motor neuron survival during embryogenesis, during postnatal development, and during regeneration in the adult but also that different motor nuclei and subpopulations of motor neurons display different requirements of Ret signaling for their survival.

\section{Retrograde GDNF/Ret signaling and synapse development}

There is good evidence that Ret activation by GDNF can increase axonal branching within the muscle and thereby influence motor neuron axons at the neuromuscular synapses. However, there are no previous data demonstrating that GDNF family members act as retrograde signals at the neuromuscular synapse and are necessary for the maturation of the presynaptic nerve terminal. Overexpression of GDNF in muscles of transgenic mice results in a marked increase of the number of motor axons innervating each muscle fiber at the developmental time when these are normally eliminated (Nguyen et al., 1998). Recent work suggests that this is attributable to an increased axonal branching within the muscle rather than an increase of motor neuron numbers or stability of synapses, which would prevent the rearrangements that normally occur (Keller-Peck et al., 2001). However, the physiological role of Ret signaling for motor synapse development and maintenance could not be addressed because of the early postnatal lethality of the Ret mutant mice. Our data show that Ret signaling plays a function by shaping structurally and molecularly the presynaptic terminals during embryonic development and adulthood, suggesting that GDNF family ligands not only affect motor axon branching but also synapse maturation. In the present study, a deficit of presynaptic maturation is defined by a reduction in the synaptic vesicle density and postsynaptic membrane covered by nerve terminals as determined using immunohistochemistry for presynaptic specialization and vesicle components (Fox et al., 2007).

Previous data suggest that synapse elimination is nearly complete in the tongue at birth (Yamane et al., 2001), which is consistent with the acquisition of new suckling and swallowing functions. Muscle endplate numbers were normal at birth in Retdeficient mice despite fewer motor neurons, whereas in the adult Ret-deficient mice, close to one-half of the neuromuscular synapses were missing. Because similar numbers of synapses were formed at E18 in Ret-deficient and control mice, growth, branching, and initial establishment of nerve muscle contact do not appear to be defective in the absence of Ret signaling. On the contrary, terminal sprouts resulting in innervation of endplates lacking motor nerve innervation may occur because there are fewer neurons generating an equal number of neuromuscular synapses in Ret-deficient mice at E18 (schematically illustrated in Fig. 5E). Consistently, terminal sprouts were often associated with motor nerve terminals in E18 Ret $^{\Delta / \Delta}$ but not control mice. A similar mechanism has been described in the adult in which partial denervation results in terminal sprouts from innervated nearby neuromuscular junctions leading to reinnervation of the postsynaptic organizations lacking motor nerve terminals (Son et al., 1996). Nearly one-half of the synapses were missing in adult Ret-deficient mice. Thus, there is a greater proportional loss of synapses than motor neurons between E18 and adult, implying that synapse loss is not secondary to motor neuron loss. Consistent with this conclusion are our data showing an important role of Ret for synapse maturation in the reinnervated adult hypoglossal target, where no additional motor neuron loss takes place. In fact, the deficits were even more pronounced in the adult with a marked deficiency of maturing axon terminals within the reinnervated muscle in the absence of Ret. It is conceivable that this deficit reflects a deferred maturation of neuromuscular synapses and, similarly the deficit of presynaptic maturation during development in the absence of Ret, could eventually catch up at later time points. Although the survival role of Ret for motor neurons is subtype- and stage-specific, the role of Ret signaling for maturation of the neuromuscular synapse might be a more general mechanism, because we found similar deficiencies in all neuromuscular synapses from various targets muscles of different motor neuron nuclei.

The phenotype on neuromuscular synapse maturation in the absence of Ret involved mostly presynaptic but also some postsynaptic deficits. We conclude that the primary deficit is in presynaptic maturation because (1) GDNF is expressed in the target tissue, (2) Ret mRNA is expressed in the motor neurons and its protein is localized presynaptically in the neuromuscular synapse, and (3) the most severe deficits were presynaptically, including the adult reinnervated synapse in which the postsynaptic organization was not much affected. Thus, the less pronounced postsynaptic alterations in these mice are likely secondary to deficits of presynaptic maturation. Our data suggest that synapse maturation is the result of a continuous cross talk between the nerve and the muscle, and GDNF ligands via Ret activation participate in this process by acting on the synaptic nerve terminal. 


\section{References}

Abercrombie M (1946) Estimation of nuclear population from microtome sections. Anat Rec 94:239-247.

Balice-Gordon RJ, Lichtman JW (1990) In vivo visualization of the growth of pre- and postsynaptic elements of neuromuscular junctions in the mouse. J Neurosci 10:894-908.

Balice-Gordon RJ, Lichtman JW (1993) In vivo observations of pre- and postsynaptic changes during the transition from multiple to single innervation at developing neuromuscular junctions. J Neurosci 13:834-855.

Baudet C, Mikaels A, Westphal H, Johansen J, Johansen TE, Ernfors P (2000) Positive and negative interactions of GDNF, NTN and ART in developing sensory neuron subpopulations, and their collaboration with neurotrophins. Development 127:4335-4344.

Bibel M, Barde YA (2000) Neurotrophins: key regulators of cell fate and cell shape in the vertebrate nervous system. Genes Dev 14:2919-2937.

Brown MC, Holland RL, Hopkins WG (1981) Motor nerve sprouting. Annu Rev Neurosci 4:17-42.

Burden SJ (2002) Building the vertebrate neuromuscular synapse. J Neurobiol 53:501-511.

Cacalano G, Farinas I, Wang LC, Hagler K, Forgie A, Moore M, Armanini M, Phillips H, Ryan AM, Reichardt LF, Hynes M, Davies A, Rosenthal A (1998) GFRalphal is an essential receptor component for GDNF in the developing nervous system and kidney. Neuron 21:53-62.

DeChiara TM, Bowen DC, Valenzuela DM, Simmons MV, Poueymirou WT, Thomas S, Kinetz E, Compton DL, Rojas E, Park JS, Smith C, DiStefano PS, Glass DJ, Burden SJ, Yancopoulos GD (1996) The receptor tyrosine kinase MuSK is required for neuromuscular junction formation in vivo. Cell 85:501-512.

Ernfors P (2001) Local and target-derived actions of neurotrophins during peripheral nervous system development. Cell Mol Life Sci 58:1036-1044.

Fox MA, Sanes JR, Borza DB, Eswarakumar VP, Fassler R, Hudson BG, John SW, Ninomiya Y, Pedchenko V, Pfaff SL, Rheault MN, Sado Y, Segal Y, Werle MJ, Umemori H (2007) Distinct target-derived signals organize formation, maturation, and maintenance of motor nerve terminals. Cell 129:179-193.

Fundin BT, Mikaels A, Westphal H, Ernfors P (1999) A rapid and dynamic regulation of GDNF-family ligands and receptors correlate with the developmental dependency of cutaneous sensory innervation. Development 126:2597-2610.

Garces A, Haase G, Airaksinen MS, Livet J, Filippi P, deLapeyriere O (2000) GFR $\alpha 1$ is required for development of distinct subpopulations of motoneuron. J Neurosci 20:4992-5000.

Garel S, Garcia-Dominguez M, Charnay P (2000) Control of the migratory pathway of facial branchiomotor neurones. Development 127:5297-5307.

Gautam M, Noakes PG, Mudd J, Nichol M, Chu GC, Sanes JR, Merlie JP (1995) Failure of postsynaptic specialization to develop at neuromuscular junctions of rapsyn-deficient mice. Nature 377:232-236.

Glazner GW, Mu X, Springer JE (1998) Localization of glial cell line-derived neurotrophic factor receptor alpha and c-ret mRNA in rat central nervous system. J Comp Neurol 391:42-49.

Godfrey EW, Nitkin RM, Wallace BG, Rubin LL, McMahan UJ (1984) Components of Torpedo electric organ and muscle that cause aggregation of acetylcholine receptors on cultured muscle cells. J Cell Biol 99:615-627.

Hamburger V (1975) Cell death in the development of the lateral motor column of the chick embryo. J Comp Neurol 160:535-546.

Henderson CE, Phillips HS, Pollock RA, Davies AM, Lemeulle C, Armanini M, Simmons L, Moffet B, Vandlen RA, Simpson LC, Koliatsos VE, Rosenthal A (1994) GDNF: a potent survival factor for motoneurons present in peripheral nerve and muscle. Science 266:1062-1064.

Heuckeroth RO, Enomoto H, Grider JR, Golden JP, Hanke JA, Jackman A, Molliver DC, Bardgett ME, Snider WD, Johnson Jr EM, Milbrandt J (1999) Gene targeting reveals a critical role for neurturin in the development and maintenance of enteric, sensory, and parasympathetic neurons. Neuron 22:253-263.

Keller-Peck CR, Feng G, Sanes JR, Yan Q, Lichtman JW, Snider WD (2001) Glial cell line-derived neurotrophic factor administration in postnatal life results in motor unit enlargement and continuous synaptic remodeling at the neuromuscular junction. J Neurosci 21:6136-6146.

Lallemand Y, Luria V, Haffner-Krausz R, Lonai P (1998) Maternally ex- pressed PGK-Cre transgene as a tool for early and uniform activation of the Cre site-specific recombinase. Transgenic Res 7:105-112.

Letinsky MS, Fischbeck KH, McMahan UJ (1976) Precision of reinnervation of original postsynaptic sites in frog muscle after a nerve crush. J Neurocytol 5:691-718.

Lu B, Je HS (2003) Neurotrophic regulation of the development and function of the neuromuscular synapses. J Neurocytol 32:931-941.

Luo W, Wickramasinghe SR, Savitt JM, Griffin JW, Dawson TM, Ginty DD (2007) A hierarchical NGF signaling cascade controls Ret-dependent and Ret-independent events during development of nonpeptidergic DRG neurons. Neuron 54:739-754.

McMahan UJ (1990) The agrin hypothesis. Cold Spring Harb Symp Quant Biol 55:407-418.

Mikaels A, Livet J, Westphal H, De Lapeyriere O, Ernfors P (2000) A dynamic regulation of GDNF-family receptors correlates with a specific trophic dependency of cranial motor neuron subpopulations during development. Eur J Neurosci 12:446-456.

Molliver DC, Wright DE, Leitner ML, Parsadanian AS, Doster K, Wen D, Yan Q, Snider WD (1997) IB4-binding DRG neurons switch from NGF to GDNF dependence in early postnatal life. Neuron 19:849-861.

Moore MW, Klein RD, Farinas I, Sauer H, Armanini M, Phillips H, Reichardt LF, Ryan AM, Carver-Moore K, Rosenthal A (1996) Renal and neuronal abnormalities in mice lacking GDNF. Nature 382:76-79.

Naveilhan P, ElShamy WM, Ernfors P (1997) Differential regulation of mRNAs for GDNF and its receptors Ret and GDNFR alpha after sciatic nerve lesion in the mouse. Eur J Neurosci 9:1450-1460.

Nguyen QT, Parsadanian AS, Snider WD, Lichtman JW (1998) Hyperinnervation of neuromuscular junctions caused by GDNF overexpression in muscle. Science 279:1725-1729.

Novak KD, Prevette D, Wang S, Gould TW, Oppenheim RW (2000) Hepatocyte growth factor/scatter factor is a neurotrophic survival factor for lumbar but not for other somatic motoneurons in the chick embryo. J Neurosci 20:326-337.

Oppenheim RW, Houenou LJ, Johnson JE, Lin LF, Li L, Lo AC, Newsome AL, Prevette DM, Wang S (1995) Developing motor neurons rescued from programmed and axotomy-induced cell death by GDNF. Nature 373:344-346

Oppenheim RW, Houenou LJ, Parsadanian AS, Prevette D, Snider WD, Shen L (2000) Glial cell line-derived neurotrophic factor and developing mammalian motoneurons: regulation of programmed cell death among motoneuron subtypes. J Neurosci 20:5001-5011.

Paratcha G, Ledda F, Baars L, Coulpier M, Besset V, Anders J, Scott R, Ibanez CF (2001) Released GFRalphal potentiates downstream signaling, neuronal survival, and differentiation via a novel mechanism of recruitment of c-Ret to lipid rafts. Neuron 29:171-184.

Pozas E, Ibanez CF (2005) GDNF and GFRalphal promote differentiation and tangential migration of cortical GABAergic neurons. Neuron 45:701-713.

Rich M, Lichtman JW (1989) Motor nerve terminal loss from degenerating muscle fibers. Neuron 3:677-688.

Rodriguez CI, Buchholz F, Galloway J, Sequerra R, Kasper J, Ayala R, Stewart AF, Dymecki SM (2000) High-efficiency deleter mice show that FLPe is an alternative to Cre-loxP. Nat Genet 25:139-140.

Rossi J, Luukko K, Poteryaev D, Laurikainen A, Sun YF, Laakso T, Eerikainen S, Tuominen R, Lakso M, Rauvala H, Arumae U, Pasternack M, Saarma M, Airaksinen MS (1999) Retarded growth and deficits in the enteric and parasympathetic nervous system in mice lacking GFR alpha2, a functional neurturin receptor. Neuron 22:243-252.

Sanchez MP, Silos-Santiago I, Frisen J, He B, Lira SA, Barbacid M (1996) Renal agenesis and the absence of enteric neurons in mice lacking GDNF. Nature 382:70-73.

Sanes JR, Lichtman JW (2001) Induction, assembly, maturation and maintenance of a postsynaptic apparatus. Nat Rev Neurosci 2:791-805.

Sariola H, Saarma M (2003) Novel functions and signalling pathways for GDNF. J Cell Sci 116:3855-3862.

Schuchardt A, D’Agati V, Larsson-Blomberg L, Costantini F, Pachnis V (1994) Defects in the kidney and enteric nervous system of mice lacking the tyrosine kinase receptor Ret. Nature 367:380-383.

Slater CR (1982a) Postnatal maturation of nerve-muscle junctions in hindlimb muscles of the mouse. Dev Biol 94:11-22.

Slater CR (1982b) Neural influence on the postnatal changes in acetylcho- 
line receptor distribution at nerve-muscle junctions in the mouse. Dev Biol 94:23-30.

Son YJ, Trachtenberg JT, Thompson WJ (1996) Schwann cells induce and guide sprouting and reinnervation of neuromuscular junctions. Trends Neurosci 19:280-285.

Terrado J, Burgess RW, DeChiara T, Yancopoulos G, Sanes JR, Kato AC (2001) Motoneuron survival is enhanced in the absence of neuromuscular junction formation in embryos. J Neurosci 21:3144-3150.

Vallstedt A, Muhr J, Pattyn A, Pierani A, Mendelsohn M, Sander M, Jessell TM, Ericson J (2001) Different levels of repressor activity assign redundant and specific roles to Nkx6 genes in motor neuron and interneuron specification. Neuron 31:743-755.

Wang CY, Yang F, He XP, Je HS, Zhou JZ, Eckermann K, Kawamura D, Feng L, Shen L, Lu B (2002) Regulation of neuromuscular synapse develop- ment by glial cell line-derived neurotrophic factor and neurturin. J Biol Chem 277:10614-10625.

Yamamoto Y, Livet J, Pollock RA, Garces A, Arce V, deLapeyriere O, Henderson CE (1997) Hepatocyte growth factor (HGF/SF) is a muscle-derived survival factor for a subpopulation of embryonic motoneurons. Development 124:2903-2913.

Yamane A, Ohnuki Y, Saeki Y (2001) Developmental changes in the nicotinic acetylcholine receptor in mouse tongue striated muscle. J Dent Res 80:1840-1844.

Yan Q, Matheson C, Lopez OT (1995) In vivo neurotrophic effects of GDNF on neonatal and adult facial motor neurons. Nature 373:341-344.

Zurn AD, Baetge EE, Hammang JP, Tan SA, Aebischer P (1994) Glial cell line-derived neurotrophic factor (GDNF), a new neurotrophic factor for motoneurones. NeuroReport 6:113-118. 